IZA DP No. 9920

Do Foreigners Crowd Natives out of STEM Degrees and Occupations?

Evidence from the U.S. Immigration Act of 1990

Tyler Ransom

John V. Winters

April 2016 


\title{
Do Foreigners Crowd Natives out of STEM Degrees and Occupations? Evidence from the U.S. Immigration Act of 1990
}

\author{
Tyler Ransom \\ Duke University
}

\author{
John V. Winters \\ Oklahoma State University
}

and IZA

Discussion Paper No. 9920

April 2016

IZA
P.O. Box 7240
53072 Bonn

Germany

Phone: +49-228-3894-0

Fax: +49-228-3894-180

E-mail: iza@iza.org

Any opinions expressed here are those of the author(s) and not those of IZA. Research published in this series may include views on policy, but the institute itself takes no institutional policy positions. The IZA research network is committed to the IZA Guiding Principles of Research Integrity.

The Institute for the Study of Labor (IZA) in Bonn is a local and virtual international research center and a place of communication between science, politics and business. IZA is an independent nonprofit organization supported by Deutsche Post Foundation. The center is associated with the University of Bonn and offers a stimulating research environment through its international network, workshops and conferences, data service, project support, research visits and doctoral program. IZA engages in (i) original and internationally competitive research in all fields of labor economics, (ii) development of policy concepts, and (iii) dissemination of research results and concepts to the interested public.

IZA Discussion Papers often represent preliminary work and are circulated to encourage discussion. Citation of such a paper should account for its provisional character. A revised version may be available directly from the author. 


\section{ABSTRACT \\ Do Foreigners Crowd Natives out of STEM Degrees and Occupations? Evidence from the U.S. Immigration Act of 1990}

This paper examines effects of the U.S. Immigration Act of 1990 on STEM (science, technology, engineering, and mathematics) degree completion and labor market outcomes for native-born Americans. The Act increased the in-flow and stock of foreign STEM workers in the U.S., both by increasing green card allotments and by expanding temporary work visas via the $\mathrm{H}-1 \mathrm{~B}$ visa program. These policy changes potentially altered the relative desirability of various college majors and occupations for natives. We examine effects of the policy on STEM degree completion, STEM occupational choice, and employment rates separately for black and white males and females. We identify the effects using variation in natives' exposure to foreign STEM workers and the geographic dispersion in foreign-born STEM workers in 1980, which precedes the Act and predicts future foreign STEM flows. We find that the Immigration Act changed natives' skill investment and utilization in three ways: (1) it pushed black males out of STEM majors; (2) it pushed white male STEM graduates out of STEM occupations; and (3) it pushed white female STEM graduates out of the workforce.

JEL Classification: J24, J61

Keywords: immigration, STEM, college major, occupation, crowd out

Corresponding author:

John V. Winters

Department of Economics and Legal Studies

Oklahoma State University

331 Business Building

Stillwater, Oklahoma 74078

USA

E-mail: jvwinte@okstate.edu 


\section{Introduction}

The impact of foreign-born skilled workers on natives is a hotly contested issue with various participants in the debate suggesting negative, positive, or neutral effects. Despite the topic's importance, there is still only limited rigorous empirical evidence, and theory is somewhat ambiguous. Kerr (2013) surveys existing literature and argues that "the global migration of talented workers ... is vastly understudied compared to its economic importance." The current paper examines effects of U.S. policy concerning foreign-born skilled workers on the education and employment outcomes of native-born Americans. Specifically, we examine effects of the U.S. Immigration Act of 1990 (IA90) on science, technology, engineering, and mathematics (STEM) degree completion and labor market outcomes for native-born Americans. We analyze these effects separately for black and white males and females.

From a policy standpoint, increasing the percentage of young people educated in STEM fields is widely viewed as vital for innovation, economic growth, healthcare, well-being, and national security (National Academies (National Academy of Sciences, National Academy of Engineering, and Institute of Medicine), 2010; President's Council of Advisors on Science and Technology (PCAST), 2012; Winters, 2014a,b). Furthermore, increasing the participation of women and minorities in STEM fields is considered important for both national economic competitiveness and equity considerations (National Academy of Sciences, 2007). However, U.S. STEM employment and the tech industry in particular are often viewed as insufficiently inclusive of women and underrepresented minorities, with STEM employment being dominated by white and Asian males (Weise and Guynn, 2014; Bidwell, 2015; Neate, 2015; Lowe, 2016; Vara, 2016). There is much concern that America is producing too few STEM graduates, especially among underrepresented 
populations, and competition from skilled foreign workers may be crowding natives out of STEM occupations and discouraging them from investing in STEM skills (Bound et al., 2013, 2015; Orrenius and Zavodny, 2015).

The Immigration Act of 1990 involved numerous significant policy changes, and President Bush (1990) called it "the most comprehensive reform of our immigration laws in 66 years." IA90 increased immigration overall and placed greater emphasis on admitting skilled immigrants by increasing the allotment of employment-based visas (Greenwood and Ziel, 1997). The Act also revised the H-1 temporary work visa program to reduce barriers for skilled workers to pursue permanent residency while on a temporary work visa (Lowell, 2001). The cumulative effect of IA90 was a significant increase in the foreign-born skilled workforce in the U.S., especially in STEM fields (Lowell, 2010; Bound and Turner, 2013).

There is considerable debate and conflicting empirical evidence about whether increases in foreign workers actually constitute adverse labor market shocks (Borjas, 1999, 2003; Card, 2001; Bound et al., 2013, 2015; Peri, Shih, and Sparber, 2015). Theory suggests that an increase in foreign-born skilled labor supply will adversely affect wage and employment outcomes for natives who are very easily substitutable with the skilled foreign workers, consistent with a downwardsloping demand curve for a particular type of labor. However, it may also be the case that skilled foreigners will be complementary with other native workers and increase their productivity. The net effect on employment and earnings is thus theoretically ambiguous. A related hypothesis is that an increased supply of foreign-born workers with particular skills is likely to encourage natives to alter their human capital investments toward skills that are less substitutable and more complementary with skilled foreigners (Peri and Sparber, 2009, 2011).

A large influx of foreign-born STEM workers has the potential to alter the college major deci- 
sions of natives as they prepare for occupations that are more complementary with foreign STEM workers. There is also some concern that minorities and women, who are already considerably underrepresented in STEM fields, may be most strongly affected (Orrenius and Zavodny, 2015). A broad literature has shown that minorities in general tend to be the most severely harmed by adverse labor market shocks (Couch and Fairlie, 2010; Hoynes, Miller, and Schaller, 2012; Hirsch and Winters, 2014). In particular, Borjas, Grogger, and Hanson (2010) suggest that labor market outcomes of black males are especially harmed by immigration. Similarly, women and minorities might be the most likely to be pushed out of STEM degrees or STEM occupations by increases in foreign STEM workers. However, the research literature on the effects of foreigners on native STEM education and employment is very thin, with Orrenius and Zavodny (2015) being a noted exception by examining the effects on native college major of same-age foreigners while natives are in school. Orrenius and Zavodny (2015) find that increases in same-age foreigners reduce STEM education for females but not males.

This paper examines reduced-form effects of increased foreign-born STEM workers on U.S. native STEM degree completion and employment by using policy changes from the Immigration Act of 1990 as a natural experiment. Specifically, we identify variation in natives' exposure to foreign STEM based on temporal differences across age cohorts and interstate differences in foreign-born shares of STEM workers in 1980, which precedes IA90 and predicts subsequent foreign STEM flows to state and local areas. We find that the Immigration Act changed natives' skill investment and utilization in three ways: (1) it pushed black males out of STEM majors; (2) it pushed white male STEM graduates out of STEM occupations; and (3) it pushed white female STEM graduates out of the labor force.

We discuss several potential explanations for our results. We suggest that the likely channel 
through which lower black STEM degree completion operates is negative expectations about future employment prospects in STEM fields as a result of increased inflows of skilled foreign-born workers. This result is consistent with research studying how students form expectations about employment outcomes for various majors and choose their own majors (Zafar, 2011; Clark, 2015; Long, Goldhaber, and Huntington-Klein, 2015; Wiswall and Zafar, 2015). Additionally, we argue that white STEM graduates were also adversely affected by the policy by being less able to find work in related occupations (or at all), which reduces earnings (Kinsler and Pavan, 2015). We suggest that IA90 harmed initial labor market conditions for highly exposed natives and that the adverse effects on entry labor market conditions had lasting effects observable roughly 20 years later, consistent with related work on persistent effects of entry labor market conditions (Kahn, 2010; Oreopoulos, von Wachter, and Heisz, 2012; Altonji, Kahn, and Speer, 2016).

There are likely numerous benefits to the U.S. from admitting high-skilled foreigners into the country. Foreign-born STEM workers in the U.S. help advance American innovation, security, and prosperity (Hunt and Gauthier-Loiselle, 2010; Kerr and Lincoln, 2010; Winters, 2014a; Peri, Shih, and Sparber, 2015). However, skilled foreigners create costs for America as well, and the costs appear to be most heavily borne by American workers who are most substitutable with foreign STEM workers. The discouragement and displacement of native STEM graduates is problematic for those individuals but also creates broader concerns about access to STEM professions for all Americans, and women and minorities in particular.

The rest of the paper is organized as follows. In Section 2, we discuss the policy background of the Immigration Act, and in Section 3 we introduce our empirical framework. In Section 4 we discuss the results, and in Section 5, we discuss potential explanations for our results. Section 6 concludes the paper. 


\section{Policy Background}

The U.S. Immigration Act of 1990 was passed by Congress on October 27, 1990 and was signed into law by President George H.W. Bush on November 29, 1990. The law became effective beginning on October 1, 1991, corresponding to the start of the U.S. Government's 1992 Fiscal Year. The Act constituted a comprehensive immigration reform that both increased immigration overall and placed greater emphasis on admitting skilled immigrants.

The Act was designed to attract skilled foreign workers, and increased immigration in two distinct and important ways. First, occupation-based immigrant visas available per year increased nearly threefold from 54,000 to 140,000 and placed increased emphasis on education and work skills (Greenwood and Ziel, 1997). Recipients of these visas immediately obtained green cards and became permanent residents. Second, IA90 also substantially revised the temporary work visa program by creating the widely publicized H-1B program for temporary work visas in "specialty occupations," many of which were STEM-related. The H-1B program also significantly reduced barriers for skilled workers on temporary visas to pursue permanent residency (Lowell, 2001). ${ }^{1}$ This is in contrast to the earlier H-1 program for temporary work visas, which was specifically designed to be temporary and came with steep barriers for obtaining permanent residence.

Over time, the various policy changes from IA90 have significantly increased the foreign-born STEM workforce in the U.S. (Lowell, 2001; Bound et al., 2013). However, the foreign STEM inflow was not equal across space. The foreign STEM workforce increased the most in areas that previously had large numbers of foreign STEM workers Kerr and Lincoln (2010); Peri, Shih, and

\footnotetext{
${ }^{1}$ The H-1B program was initially capped at 65,000 visas per year. Demand grew quickly, and the H-1B cap was raised to 115,000 in 1998 and then to 195,000 in 2000 before being reduced to 85,000 in 2004 (with exemptions for academic, non-profit, and governmental research institutions). STEM occupations are heavily represented among H1B visas and the program has played a major role in growing the foreign STEM workforce in the U.S.; see Kerr and Lincoln (2010) for more details.
} 
Sparber (2015). Newly arriving immigrants and temporary workers have historically tended to locate in areas where persons from the same national origin reside in order to take advantage of social networks and cultural and linguistic similarity Card (2001). This pattern continued after IA90. States with previously high levels of foreign STEM workers, like California, New York, and Washington, tended to receive the largest inflows of foreign STEM workers after 1990. However, such states have also generally experienced the largest booms in demand for STEM workers, especially related to the information and communication technology (ICT) revolution. Thus, examining the effects of increased foreign STEM workers on natives requires careful consideration.

\section{Empirical Framework}

This section outlines the data, identifying assumptions, and empirical strategy that we follow in order to estimate the impact of IA90 on native skill investments and utilization.

\subsection{Data}

The primary data used in our analysis come from the 2009-2014 American Community Survey (ACS) microdata extracted from IPUMS (Ruggles et al., 2015). The ACS annually surveys one percent of the U.S. population and includes individual information on age, sex, race, Hispanic ethnicity, state of birth, occupation, employment status, highest education completed, and bachelor's degree college major for those completing a bachelor's degree or higher. We use the ACS college major information to define STEM college majors based primarily on definitions used by U.S. Immigration and Customs Enforcement. The full list of ACS majors coded as STEM is reported in Appendix Table A1. A few graduates report double majors. We classify them as a STEM graduate 
if either the first or second major is in a STEM field. Our main definition for STEM occupations includes persons working as engineers, mathematicians, natural scientists, computer scientists, and computer software developers, but we also examine robustness to considering a broader definition that includes health-diagnosing occupations (and STEM field college instructors in our 1980 definition). The list of STEM occupations is included in Appendix Table A2.

\subsection{Identifying Assumptions}

An important assumption for our later analysis is deciding which individuals were most exposed to the increased inflow of skilled foreign-born workers. Following existing literature, we measure the timing of increased foreign STEM shocks from IA90 for natives based on the year they were 18 years of age. We compute the year age 18 as the ACS calendar year minus age at the time of the survey plus $18 .^{2}$ We do not observe in the data when someone graduated high school, attended college, or chose their college major, but we follow previous literature and assume that individuals graduate high school, begin college, and choose their major at age 18 (Dynarski, 2008; Malamud and Wozniak, 2012; Orrenius and Zavodny, 2015; Sjoquist and Winters, 2014, 2015). To isolate the effects of IA90, we restrict our main analysis to persons who were age 18 in years 1986-1994; these persons were ages 33-46 in 2009-2014. We assume that persons age 18 in 1986-1989 made their educational decisions independent of IA90, while persons age 18 in 1991-1994 were potentially affected by IA90. We exclude persons age 18 in 1990 because they may be partially affected, but not as strongly affected as later cohorts. Their inclusion would likely increase measurement error in the treatment from IA90. ${ }^{3}$ By including year 1991 in the treatment, we allow for both

\footnotetext{
${ }^{2}$ For example, a person surveyed in the year 2010 who was age 36 at the time of the survey would have been 18 in the year 1992.

${ }^{3}$ In reality, the 1986-1989 cohorts could have been partially affected also. If so, assuming that they are unaffected would induce measurement error in the treatment from IA90 and attenuate pre- and post-IA90 outcome differences
} 
the announcement and implementation of IA90 to affect the outcomes we analyze. We present evidence that both effects contribute to our findings.

Our primary analysis focuses on cohorts four years before and after the treatment to isolate the effects of IA90. Examining a longer time period could cause other policy changes and economic shocks to confound the analysis. However, we discuss below the robustness of our main results to moderate expansions in the time period examined.

Our analysis exploits geographic variation in foreign STEM exposure before and after IA90. To do so, one might initially seek to measure the actual presence of foreign STEM workers by year across states or other geographic areas. However, we do not take this approach for two main reasons. First, using contemporaneous measures for foreign STEM presence and native STEM education would likely cause the relationship to be confounded by unobserved demand shocks for STEM workers that ceteris paribus increase both native STEM education and foreign STEM in-flows. We could attempt to control for STEM demand shocks, but doing so is no easy task and concerns would remain. Second, there is a lack of annual data on foreign STEM workers during this time period. Decennial census data could be used for 1980, 1990, and 2000, but not for intercensal years. The census provides intercensal population estimates, but not by occupation. Another potential data source is the Current Population Survey (CPS), which is conducted annually and includes occupation information. However, it does not report citizenship or foreign birth status prior to 1994 and cannot be used to confidently construct measures of foreign STEM workers for the period needed for this study. The CPS sample size for individual states is also relatively small and as a result would produce noisy time-varying estimates of foreign STEM workers even if toward zero. We examine the robustness of our treatment assumptions and find that our primary findings are quantitatively, but not qualitatively affected. These results are available from the authors upon request. 
foreign-born persons were identifiable. ${ }^{4}$

Our empirical approach is to measure foreign STEM exposure using an interaction term between the year 1980 foreign STEM share in one's birth state and a dummy for cohorts reaching age 18 in 1991 and later. We measure the foreign STEM share as the share of college-educated STEM workers ages 25-59 who are foreign born in each state in 1980 using the 1980 census $5 \%$ microdata file from IPUMS (Ruggles et al., 2015). The foreign STEM share is measured for 1980 instead of 1990 so that it is determined before our 1986-1989 control group cohorts make initial education decisions at age 18, and so that it precedes the ICT revolution that increased demand for technical skills including those in STEM.

The motivation for using the 1980 foreign STEM share is that previous research inclines us to expect IA90 to increase the foreign STEM workforce the most in areas that already had large numbers of foreign STEM workers (Kerr and Lincoln, 2010; Peri, Shih, and Sparber, 2015). This relationship is illustrated in Figure 1. We compute the foreign STEM share by state in 1990 and 2000 using the decennial census 5\% files and then compute 1990-2000 changes. Regressing the 1990-2000 change in the foreign STEM share on the 1980 foreign STEM share yields a positive

\footnotetext{
${ }^{4}$ Besides the ACS, two additional datasets record an individual's college major and place of birth: the Survey of Income and Program Participation (SIPP) and the National Survey of College Graduates (NSCG). The SIPP is a repeated panel survey spanning the years 1984-2013, with cross-sectional sample size and survey questions comparable to the CPS. The NSCG is a repeated cross-section survey of college graduates that collects detailed information on an individual's major, college characteristics, and occupation at the time of the survey. Survey years of the NSCG include 1993, 2003, 2010, and 2013. We do not use the SIPP for the same reason that we do not use the CPS - the sample size of college graduates within individual states is too small to produce meaningful estimates. The 1993 wave of the NSCG provides information on a respondent's state of birth, but later panels do not. We are unable to make use of the 1993 wave because there are no respondents in our treatment group (i.e. the most recent college graduates in the sample graduated in 1990). We cannot make use of later waves because birth state is unobserved. Finally, the Integrated Postsecondary Education Data System (IPEDS) collects information on annual degrees awarded for many institutions in the United States. However, IPEDS degree totals are based on the location of the institution and year conferred and not broken down by state of origin or year of matriculation or high school graduation. This makes identification of IA90 effects via timing and geography especially difficult because of measurement error and potential unobservable shocks, like the ICT boom, that might increase STEM student in-migration to areas with high foreign STEM exposure. Our analysis using ACS data overcomes these challenges by exploiting identifying variation based on year and state of birth.
} 
coefficient of 0.467 that is statistically significant at greater than the $1 \%$ level with an $R^{2}$ of 0.338 . This indicates that areas with already high foreign STEM share in 1980 saw especially large increases in foreign STEM shares during the 1990s following IA90. As noted above, data limitations prevent us from constructing measures of annual growth in the foreign STEM share. However, it seems likely that the college major decisions of native-born Americans would be affected both by the actual increase in the foreign STEM workforce during their college years as well as their expectations about future increases.

We follow previous literature and utilize state of birth in examining effects of IA90 to exploit differential exposure to increased foreign STEM workers across states. The ACS does not report the location where someone attended high school or college, but the state of birth variable has been used as a proxy for these by previous researchers (Dynarski, 2008; Malamud and Wozniak, 2012; Orrenius and Zavodny, 2015; Sjoquist and Winters, 2014, 2015). Sjoquist and Winters (2014) report that in 1990, roughly three-fourths of persons ages 15-17 resided in their state of birth. Since some young people do move out of their birth-state before finishing high school and starting college, the birth-state exposure assumption will induce some degree of measurement error, which is likely to attenuate coefficient estimates toward zero.

One threat to our identification strategy is the presence of merit-based scholarship programs, which have been shown to impact students' college major decisions. For example, Sjoquist and Winters (2015) find that state adoption of "strong" merit-based scholarship programs causes students to shift away from STEM majors. Georgia is the only state to adopt a strong merit aid program during the 1986-1994 time period, but Arkansas, Missouri and North Dakota also adopted weaker programs during this period. To avoid potential confounding effects from merit aid policies, our primary analysis excludes these four merit states. However, our results are highly robust 
to including these four states.

We examine the effects of foreign STEM exposure on native STEM degree rates by estimating variants of the following linear probability model (LPM): ${ }^{5}$

$$
\operatorname{Pr}\left(Y_{i s c t a}=1\right)=\theta \text { ForeignSTEMexposure }_{s c}+\Gamma_{s}+\Pi_{c}+\Psi_{t}+\Omega_{a}+\beta Z_{s c}+\delta_{s} T_{s c},
$$

where $Y_{\text {iscta }}$ is a binary variable for individual $i$, from birth-state $s$, in year-age-18 cohort $c$, observed in the ACS during survey year $t$ at age $a$. We primarily examine three separate outcomes in which $Y_{i s c t a}$ equals one for persons meeting the following conditions: (1) graduating with a four-year college degree in a STEM field; (2) working in a STEM occupation during the 2009-2014 ACS reference period; and (3) employed in any occupation during the 2009-2014 ACS reference period. As robustness checks, we also examine and discuss results corresponding to additional outcomes related to the three listed.

The primary explanatory variable of interest is ForeignSTEMexposure ${ }_{s c}$, which measures an individual's exposure to increased foreign STEM workers resulting from IA90. This variable is defined to be zero for 1986-1989 year-age-18 cohorts. For 1991-1994 year-age-18 cohorts, ForeignSTEMexposure $_{s c}$ is measured as the 1980 foreign STEM share in the individual's state of birth. Formally, it is defined as

$$
\text { ForeignSTEMexposure }_{s c}=1[c>1990]\left(\frac{N_{1980, S T E M, s, \text { foreign }}}{N_{1980, S T E M, s}}\right)
$$

Where $N_{1980, S T E M, s}$ refers to the number of college-educated workers (age 25-59) in state $s$ in 1980

\footnotetext{
${ }^{5}$ We estimate linear probability models instead of probit or logit models for simplicity and ease of interpretation. LPM is very common in the policy evaluation literature when models include a high dimension of fixed effects and facilitates easier interpretation of marginal effects.
} 
who were working in a STEM occupation. Similarly, $N_{1980, S T E M, s, \text { foreign }}$ is the number of collegeeducated workers (age 25-59) in state $s$ in 1980 who were working in a STEM occupation, and who

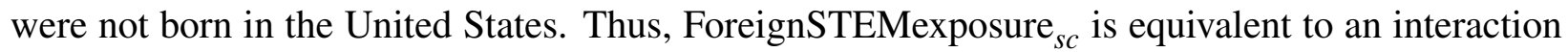
term between the 1980 foreign STEM share and a dummy for cohorts who were age 18 in 1991 or later. We estimate the model separately for native-born black and white males and females. ${ }^{6}$ All estimates use sample weights. Standard errors are clustered by birth state to account for possible serial correlation within states.

The model includes birth-state fixed effects $\left(\Gamma_{s}\right)$ and year-age-18 cohort effects $\left(\Pi_{c}\right)$, which respectively control for time-invariant differences across birth-states and aggregate time differences across cohorts. Thus, identifying variation comes from differences across cohorts within states. The setup is similar to a traditional difference-in-differences framework, with two exceptions: (1) the treatment is continuous instead of binary; and (2) all states receive varying levels of treatment after the policy change. Conceptually, we are comparing the pre- and post-IA90 withinstate change in native STEM outcomes across states with differing treatment intensities. If IA90 caused foreign STEM workers to crowd natives out of STEM majors, STEM occupations, or the labor force, we would expect this to be most pronounced in states receiving the largest dose of treatment. This would induce a negative coefficient for $\theta$.

The model also includes survey year effects $\left(\Psi_{t}\right)$ and age effects $\left(\Omega_{a}\right)$. Because we observe cohorts at ages 33-46 and also include year age 18 cohort dummies, these effects control for aggregate business cycle variation during the ACS survey years and variation in the time duration

\footnotetext{
${ }^{6}$ Throughout this study, we refer to white and black individuals as those who are not Hispanic. We do not include Hispanics nor Asians in our analysis because native Hispanics and Asians are very often the children or grandchildren of immigrants and parental birthplace is unobserved in our data, and because assimilation differences across cohorts and states are unobserved and likely affect our outcomes of interest. Other racial groups are also not examined because they yield small ACS samples that prevent reasonably precise inferences.
} 
between age 18 and the time of the survey.

Additionally, our models include time-varying state-level control variables $\left(Z_{s c}\right)$ measured for the year age 18 in one's birth state and birth-state by year-age-18 linear time trends $\left(T_{s c}\right)$. The $Z_{s c}$ variables include log cohort size at age 18 computed from U.S. Census Bureau intercensal population estimates, the state unemployment rate obtained from the U.S. Bureau of Labor Statistics, and the log of median household income computed from the Current Population Survey. Statespecific time trends account for other unobservable factors, e.g., increased relative demand for STEM skills.

Our identification strategy assumes that the within-state variation across cohorts in the foreign STEM exposure variable is conditionally correlated with the outcomes we consider only through the effects of IA90. For college major decisions, this assumes that there were no other major changes in policy or economic conditions systematically related to the 1980 foreign STEM share at the same time as young people were making college major decisions. We have extensively searched the literature and found no such policy changes that could significantly affect the results. However, we do have some concern that the ICT revolution could have increased demand for STEM skills the most in states with previously high shares of foreign STEM graduates. We discuss below robustness checks that attempt to address this concern.

For our more recent employment outcomes, we hypothesized at least two factors that could affect our estimates. First, the post-IA90 inflow of foreign-born STEM workers could affect the recent employment outcomes of pre-IA90 cohorts, meaning that the control group receives treatment also. Second, the post-IA90 inflow of foreign-born STEM workers could push native workers

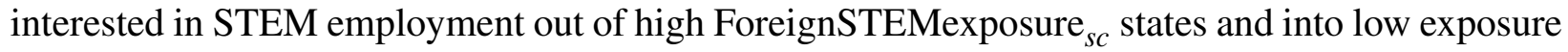
ones, which would effectively increase exposure in low exposure states. In general, both of these 
concerns would likely attenuate estimates toward zero relative to the true effects. However, we do expect that our estimation strategy could detect at least some differences in recent employment outcomes.

Table 1 panel A reports weighted summary statistics for the 1991-1994 cohorts for the foreign STEM exposure, separately by race-sex combination. By construction, the measure equals zero for the 1986-1989 cohorts. The 1980 foreign STEM share has weighted mean of 0.121 and 0.118 for blacks and whites, respectively, with no observable difference by sex. For all groups, the standard deviation is 0.057 , the $\min$ is 0.018 , and the $\max$ is 0.216 . Table 1 panel B reports race-sex means for the main outcome variables we consider. More on the outcome measures is discussed below. The summary statistics in Table 1 will be useful later for assessing the effect magnitudes of IA90.

\section{Empirical Results}

In this section, we detail the empirical results of our model. We focus on three separate effects of the Immigration Act of 1990: (1) college major choice of natives directly after the policy was enacted; (2) occupational choice of natives roughly 20 years after the policy; and (3) employment rate of natives roughly 20 years after the policy.

\subsection{College Major Choice}

We first examine whether the Immigration Act of 1990 influenced the choice of college major for natives. To do so, we estimate equation (1) where the dependent variable is an indicator for if the individual graduated college with a major in a STEM field.

Table 2 shows the effect of birth-state foreign STEM exposure on native STEM degree attain- 
ment, unconditional on education level. We find that, while females and white males are unaffected by the policy, black males are a notable exception and are much less likely to major in a STEM field as a result of the policy. ${ }^{7}$ Furthermore, the magnitude appears quite large. Combining the coefficient of -0.241 with the summary statistics in Table 1 suggests that a two standard deviation difference in foreign STEM exposure reduces black STEM degree completion by 2.8 percentage points. This is roughly 70 percent of the pre-IA90 mean STEM degree rate for black males.

To assess whether the negative effect for black males in Table 2 is driven by decreased bachelor's degree attainment or decreased STEM attainment conditional on bachelor's attainment, we present Tables 3 and 4 . These tables show that overall bachelor's degree attainment was unaffected by the policy, but that black males were much less likely to major in STEM conditional on graduating college. Scaling the Table 4 black male coefficient of -1.377 by Table 1 summary statistics suggests that a two-standard deviation difference in IA90 foreign STEM exposure reduced STEM degrees by 15.8 percentage points among black male college graduates, which corresponds to roughly 64 percent of the pre-IA90 mean for black males. The other demographic groups we examine are not meaningfully affected in either of the separate dimensions in Tables 3 and 4.

The results lead one to wonder if black males disproportionately switched into certain nonSTEM majors, or if they disproportionately switched out of certain STEM majors. To analyze this possibility, we report in Tables 5 and 6 estimates similar to those in Table 2, but where instead the dependent variable is graduation in a specific major. Table 5 shows that the most popular destination majors for black males were business and liberal arts majors, although the specific effects

\footnotetext{
${ }^{7}$ While not the focus of our study, the much smaller sample size for black males relative to black females is quite alarming. This is consistent with census population estimates and vital statistics showing disturbingly high mortality rates for black males. The ACS includes samples of the institutionalized population and they are included in our analysis. However, our results are not affected by controlling for the size of black male cohorts or non-institutionalized cohorts. Higher mortality and institutionalization are unlikely to affect marginal STEM graduates in ways correlated with our foreign STEM exposure measure.
} 
are imprecisely estimated and we cannot reject uniformity in the distribution of destination field switches. Table 6 shows a similar effect for STEM majors: biological sciences, computer science, and math were the majors that black males switched away from at the highest rates, although none of these effects is significantly different from any of the others.

Finally, we examine the temporal effects of the policy by breaking out Table 2 by cohort year and excluding state-year trends. To do so, we estimate a variant of equation (1) where $\theta$ is indexed by $c$ (i.e. allowed to vary by year-age-18 cohort) and estimated for each year of the 1986-1994 period, with the 1990 year-age-18 cohort now included in the sample and defined as the omitted base category. We present the results of this equation in Table 7. Single-year estimates are imprecise as one would expect, but the strongest effects of the policy for black males were in years 1991 and 1993, followed by 1992. This underscores the likelihood that the policy had strong announcement effects as well as implementation effects on STEM degree completion of black males. Furthermore, we observe an apparent pre-1990 upward trend in the coefficients likely because of the growing demand for STEM skills in high foreign-STEM areas related to the ICT revolution. This reinforces the importance of controlling for state-specific time trends in our main analysis. We discuss implications of these results later.

\subsection{STEM Occupation Employment}

We now examine the effect of IA90 on the probability of having a STEM occupation during the 2009-2014 ACS. $^{8}$ Our main STEM occupation variable includes those currently employed in a

\footnotetext{
${ }^{8}$ We emphasize that, although this period of time corresponds to the Great Recession and recovery, our identifying variation comes from within-state differences in outcomes, compared across birth cohorts and birth states. Furthermore, our inclusion of calendar-year fixed effects controls for differences in our outcomes at the national level. Finally, we repeat the analyses using only the years 2013 and 2014 (which correspond most closely to a "normal" economy) and find qualitatively similar results. These are available from the authors upon request.
} 
STEM occupation and those not currently employed but whose most recent occupation and within the past five years was in a STEM field. We first analyze the impact of the policy on working in a STEM occupation, unconditional on education level. Panel A of Table 8 reports that white males were negatively impacted by the policy, but that the other demographic groups were not at all affected.

Panels B and C of Table 8 examine the effect of the policy on STEM occupation, conditional on bachelor's degree attainment, and conditional on STEM degree attainment. ${ }^{9}$ We find that white males are again the only significantly negatively impacted group in panel B, but white females are also negatively impacted when considering those with degrees in STEM fields. ${ }^{10}$ For completeness, panel D examines effects on STEM occupation for college graduates whose undergraduate major was in a non-STEM field; IA90 had no significant effect.

The results in Table 8 include those who are currently unemployed but recently employed in a STEM occupation. In Table 9, we report the analog of Table 8 for current employment in a STEM occupation, and find very similar effects.

The effect magnitudes for white males in Tables 8 and 9 are economically large. For example, the Table $8 \mathrm{c}$ coefficient of -0.681 implies that a two standard deviation increase in the foreign STEM exposure variable reduces the probability of working in a STEM occupation for white male STEM graduates by 7.7 percentage points, which corresponds to roughly 26 percent of the mean for pre-1990 cohorts.

\footnotetext{
${ }^{9}$ We encourage caution in interpreting results for black males that condition on being a STEM graduate since IA90 altered the conditioning variable. If the black males pushed out of STEM majors by IA90 systematically differ from those who remain in terms of ability or STEM workforce attachment, results conditioning on STEM major may suffer from selection bias.

${ }^{10}$ In results not shown, we also separated STEM occupations into 1) engineers, 2) computer scientists and software developers, and 3) mathematicians and natural scientists. The first two groups combine to account for 84 percent of STEM graduates in STEM occupations in our sample and account for a great majority of the negative effect of IA90 on STEM occupations in panel C of Table 8.
} 


\subsection{Employment Rate}

Next, we examine the impact of IA90 on employment during the prior week in the 2009-2014 ACS.

To do so, we estimate equation (1) where the dependent variable is an indicator for employment, unconditional on labor force participation. As such, the dependent variable is an individual-level analog to the employment-to-population ratio. ${ }^{11}$

Table 10 reports the effect of the policy on employment rates for each demographic group. We show in panel A that, unconditional on educational attainment, black males were more likely to be employed and black females less likely so. When restricting to the sample of college graduates in panel B, these results are not statistically significant. However, when restricting to the sample of college graduates in STEM fields in panel C, we find that white male and white female employment were adversely affected by the policy. ${ }^{12}$ Finally, we show in panel $\mathrm{D}$ that the policy had little effect on employment among college graduates outside of STEM fields.

The results of Table 10 illustrate the complex response to the policy. While whites were adversely affected, Table 10c also yields a large negative but insignificant effect on employment for black women. Black males have a large positive (but insignificant) coefficient in Table 10c. While black males shift away from STEM majors, those who stay in STEM majors have higher employment and STEM occupation rates, potentially consistent with changing quality and/or workforce attachment. But whites (and black females) don't change their major and those who major in STEM experience lower employment and STEM occupation rates due to IA90 (though not signif-

\footnotetext{
${ }^{11} \mathrm{We}$ abstract from labor force participation because it is likely dependent on labor demand and other employment conditions.

${ }^{12}$ In results not shown, we did separate these negative effects into portions reported as unemployment and labor force non-participation. For white male STEM graduates, the effect is mostly due to reported unemployment. For white female STEM graduates, the effect is mostly due to reported non-participation. However, potential labor force withdrawal of discouraged workers dissuades us from offering strong conclusions on this.
} 
icant for black females).

As a similar measure of employment, we consider the likelihood that an individual worked at all in the past year. We repeat the analysis in Table 10, and find slightly different but interesting results. For example, Table 11b shows significantly positive effects of IA90 on the likelihood of working in the last year for college educated black males and females. Once we condition on graduating with a STEM major, Table 11c shows a significant negative effect on white females and an insignificant but large negative effect on black women that is nearly equal to the white female effect. There is no effect on white males and a positive but insignificant coefficient for black males. In Table 11d, we examine the response of non-STEM college graduates and find that black males and females and white males experience positive employment effects from the policy. These positive effects might be due to complementarities with foreign STEM workers, or the black male coefficient could also be due to changing unobservables induced by major switching.

The annual employment results in Table 11 are somewhat consistent with current employment results in Table 10. The lack of a negative effect for white males in Table 11c appears to suggest that white males are quicker to accept a less desirable job (e.g. in a non-STEM job as shown in Table 9c) than females, who are more likely to remain non-employed (Table 10c). In results not shown, we also examined whether STEM graduates had worked in the past five years. IA90 also significantly reduced the probability of working in the past five years for white female STEM graduates with magnitude comparable to Tables Table 10c and Table 11c.

In summary, we find that IA90 had three main effects that differ by race-sex group: (1) it pushed black males out of STEM majors; (2) it pushed white males out of STEM occupations; and (3) it pushed white females out of the workforce. 


\subsection{Log Earnings}

We next consider log annual earnings as an outcome, which is reported in the ACS as the earned income during the 12 months prior to the survey. Non-workers have zero earnings and some self-employees have negative earnings, yielding undefined log earnings. For simplicity, our initial analysis drops individuals with zero or negative earnings, but we consider alternatives.

Table 12 reports results for different education samples as in previous sections. Panel A reports results unconditional on education and shows negative but statistically insignificant coefficients for all four groups considered. Panel B restricts the sample to college graduates, where we now see a much larger negative coefficient for black males that is statistically significant at the ten percent level. Coefficients for the other groups are again statistically insignificant. Panel C restricts the sample to STEM graduates. The coefficients are again all negative but not statistically significant. The magnitudes, however, are quite large. For example, the coefficients for black males and females suggest that a two standard deviation increase in foreign STEM exposure reduces log earnings by roughly 0.17 implying a roughly 17 percent reduction in annual earnings.

A few points are worth noting about the earnings analysis. First, the results for black males by major are potentially affected by selection since IA90 reduced black male STEM degree completion. If lower quality students are the ones pushed out of STEM, the true effect might be even greater than that which is estimated. Second, it seems plausible that pre-IA90 cohorts could also be partially treated which would attenuate our estimates relative to the true effect. Third, pooling male and female STEM graduate samples by race in panel $\mathrm{C}$ increases precision and gives negative coefficients estimates for both races that are statistically significant at the ten percent level. Fourth, we estimated results not shown that compute mean earnings by age-year-race-sex cells for STEM 
majors that include zero and negative earners and examined log mean earnings as an outcome and obtained qualitatively similar results as in panel $\mathrm{C}$, though the coefficients for black female and white female STEM graduates increase in magnitude and becoming significant at the ten percent level.

Unfortunately, these earnings results are not precisely estimated but they are suggestive of adverse effects of IA90 on natives. Native STEM graduates are likely negatively affected by increased exposure to foreign STEM. Furthermore, black males also suffer the burden of being pushed out of STEM majors, giving a large negative effect that is statistically significant among the sample of all college graduates.

\subsection{Sensitivity Analysis}

In results not shown but available from the authors, we estimated the effects of IA90-induced foreign STEM exposure on our outcomes using several alternative specifications. Our main results are qualitatively robust to reasonable alternatives. Alternatives examined include:

- Expanding the pre- and post-IA90 year-age-18 sample window to five or six years on either side of the policy change.

- Excluding very high immigration states from the analysis such as California, Florida, Illinois, New York, Texas, and Washington.

- Using the expanded definition of STEM occupations in Table A2 to measure foreign STEM exposure and for the native STEM occupation outcome.

- Excluding state control variables. 
- Adding a time-varying state control for the 1980 (or 1990) share of native college graduates in the state employed in STEM occupations interacted with the post-IA90 dummy to account for possible ICT effects related to past STEM employment.

- Including cohorts age 18 in 1990 in the control group.

\section{Discussion}

In this section, we discuss potential pathways through which each of our main findings may be operating. Specifically, we discuss possible explanations for why black males switch away from STEM majors, why white males are less likely to be employed in STEM occupations, and why white females are less likely to be employed, as well as the implications of our empirical results.

\subsection{Black males switching out of STEM majors}

The most surprising result from our analysis is the shift of black males out of STEM degree fields in consequence of the increased inflow of foreign-born STEM workers. When considering potential reasons for why black males switched out of STEM majors, it is helpful to consider the prominent explanations for why STEM degree rates are so low among this population to begin with. We consider six explanations, and suggest that the primary explanation for black males switching away from STEM majors is that they had especially low expectations about their STEM employment prospects because of increased inflows of foreign-born STEM workers. The six reasons we discuss

are: (1) worse pre-college academic resources and preparation that result in poor student-campus matches for STEM persistence; (2) lack of similar role models in STEM; (3) cultural norms that equate academic effort and achievement with "acting white"; (4) perceived low compatibilities 
between blacks and foreigners; (5) negative perceptions and low expectations for them by others (teachers, family, community members, etc.); and (6) low self-confidence in one's STEM abilities and chances for future STEM success.

First, the shift of black males out of STEM fields could be due to differing preparation levels of this group relative to the other groups we analyze. The literature on student preparation and major choice concludes that an important cause of minority STEM achievement is the student-campus match (Griffith, 2010; Arcidiacono, Aucejo, and Spenner, 2012; Arcidiacono, Aucejo, and Hotz, 2016). However, it is unlikely that this effect explains the results we have found for IA90, because IA90 was a national policy that encompassed a variety of student-campus matches. Indeed, for this effect to operate, it would had to have been the case that states with high immigrant STEM stocks also happened to be states where black male students suddenly began attending worse-matched institutions beginning after $1990 .^{13}$

Second, the response of black males could be due to a lack of role models in STEM. Price (2010) finds that black students are more likely to persist in a STEM major if they take a STEM course taught by a black instructor. Similarly, Griffith (2014) finds a role-model effect where students earn higher grades in courses taught by same-gender instructors in fields traditionally dominated by the opposite gender. However, for this effect to explain our findings, there would had to have been a sudden and sharp decline in black STEM professors and graduate students on campuses in states with high stocks of foreign-born STEM workers. While some of the foreignborn workers that came to the U.S. as a result of IA90 may have been STEM professors, it is unlikely that the number of such professors would have been large enough to generate the effects

\footnotetext{
${ }^{13}$ In results not reported, we attempt to address this question by eliminating the Southern United States from our analysis, where black college students are most likely to be educated at historically black colleges and universities (HBCUs). Our results are actually stronger when excluding these states.
} 
that we measure.

A third potential explanation is the notion that earning a STEM degree may be perceived by peers as "acting white" (Austen-Smith and Fryer, 2005; Fryer and Torelli, 2010). Black peers may actively discourage such behaviors attributed to non-peer groups, and those defying peer group norms may face peer ridicule and social isolation. However, this effect is unlikely to have operated differently before and after the announcement and implementation of the Immigration Act of 1990 and between high foreign STEM states and low foreign STEM states.

A fourth possibility related to the third is that black males may have responded to perceived labor market and cultural conflicts between blacks and foreigners. A sizable literature in the social sciences discusses displacement of black workers by foreigners in a variety of occupations and local labor markets (Beck, 1996; Waldinger, 1997; Borjas, Grogger, and Hanson, 2010). There is also evidence that some immigrant small business owners have strongly discriminated against hiring black workers (Kaufman, 1995). There is also a widely held perception of cultural conflict between immigrant business owners in predominantly black neighborhoods and the black customers they serve (Chang, 1993). While this mechanism could be contributing to our results, we argue that it is not the driving component of college major choice.

Fifth, it could be the case that teachers and family members of black males have especially low expectations for their performance in STEM fields. This may be an explanation for why black males switched out of STEM, but it is difficult to test. For example, it could be the case that, after hearing the announcement of the immigration policy, parents and teachers of high-school aged black males directly or indirectly encouraged them to choose non-STEM fields so as not to have to compete with incoming foreign-born workers. An important piece of empirical evidence that supports this explanation is Card and Giuliano (2015), who document that minority elementary 
school students in Florida are less likely to be recommended for gifted programs when the recommendation is done by parents and teachers. Recommendation rates for this group of students increase markedly when standardized test scores are used instead.

After reviewing the literature on why differences exist in STEM attainment by race and gender demographic groups and considering the empirical evidence, we argue that the most likely channel through which IA90 lowering black STEM degree completion operates is a sixth channel, negative student expectations about future success in STEM fields as a result of increased inflows of skilled foreign-born workers. The empirical evidence in Table 7 shows strong announcement effects for the earliest treated cohorts, even before the foreign inflows were likely to have large impacts on STEM labor markets. This result is consistent with research studying how students form expectations about their majors (Zafar, 2011; Wiswall and Zafar, 2015). What is unclear, however, is which information the students would have used to modify their beliefs about future success. The information may have originated from family members, students' own media consumption, or high school and university guidance counselors, creating important links between the fifth and sixth mechanisms. Similarly, black males may have been especially pessimistic about their post-IA90 STEM prospects because of past cultural and labor market conflicts between blacks and immigrants, thus connecting the fourth and sixth mechanisms. Furthermore, limited resources, preparation, role models, and peer discouragement could have made some black males especially sensitive to STEM labor market shocks on their choice of college major.

Our results emphasize an important parallel between in-migration of foreign-born STEM workers and internal migration of native STEM workers. To the extent that state and local governments attempt to attract and retain highly skilled workers in STEM fields, it may be the case that black males are similarly dissuaded from choosing STEM majors when faced with an increased inflow 
of native STEM workers. However, if the cultural conflict mechanism is the strongest deterrent to black STEM achievement, then local governments' efforts to attract native STEM workers will not be as harmful to this group. However, if any large and sudden inflow of STEM workers (regardless of nationality) diminishes the labor market expectations of this group, then internal migration and foreign in-migration will have the same effect on STEM achievement. Unfortunately, we are unaware of a natural experiment that would allow us to test the possibility of internal migration as a crowd-out mechanism.

\subsection{White males less likely to work in STEM occupations}

Our second principal empirical result concerns the impact of IA90 on the likelihood of STEM occupations. As discussed earlier, we find that white male college graduates are less likely to be employed in a STEM occupation during the ACS survey period. This result is amplified when restricting attention to STEM graduates, where both white males and white females are adversely affected.

Our finding of adverse occupation effects falls in line with other research in the literature that shows that immigration shifts natives to fields in which they have a comparative advantage (Peri and Sparber, 2009, 2011). Our finding of movement away from STEM occupations is consistent with this line of literature if white STEM graduates are less prepared to work in STEM jobs or more prepared to work in complementary fields (e.g. management and marketing) than their foreignborn counterparts. Furthermore, the timing of foreign inflows likely affects which natives are most affected. STEM graduates age 18 in the early 1990s faced much greater labor market exposure to foreign STEM workers than those age 18 in the late 1980s. We suggest that IA90 likely reduced 
initial STEM employment for highly exposed natives and that this had lasting effects observable roughly 20 years later, consistent with persistent effects of entry labor market conditions found in Oreopoulos, von Wachter, and Heisz (2012) and Altonji, Kahn, and Speer (2016).

Kinsler and Pavan (2015) examine the wage returns to working in a related occupation for STEM majors. They find that working in a related occupation causes STEM graduates to have $30 \%$ higher earnings than STEM graduates who are working in unrelated occupations. This result is in addition to the sizable wage returns to majoring in STEM that are well documented in the literature. When viewed through the lens of our results, the return to working in a related occupation implies that whites' decreased likelihood of working in STEM majors could have significant welfare impacts, even though our earnings estimates are noisily estimated.

Interestingly, while black males are less likely to major in STEM as a result of the policy, the black students who do graduate in STEM are no less likely to find STEM jobs after graduation. While this result may seem to indicate that avoiding STEM majors was helpful to black males, there are likely significant adverse welfare affects because of the substantial earnings differentials between STEM and non-STEM majors, regardless of occupation relatedness.

\subsection{White female STEM graduates less likely to be employed}

Finally, we discuss potential reasons for why white female STEM graduates are less likely to be employed as a result of the policy. As discussed previously, we find evidence that white female STEM graduates were less likely to find employment in STEM occupations. We focus here on the additional finding that they were less likely to be employed in general. This effect is especially stark, because white female STEM graduates in our sample have a labor force participation rate 
that is 1.8 percentage points higher than non-STEM graduates, and employment rates that are 2.3 percentage points higher.

This career-oriented pathway could be influenced by increased competition among STEM occupations precipitated by the increased inflow of STEM-educated foreign-born workers. Entry labor market conditions of a graduating cohort can have lasting effects in terms of employment and occupational attachment (Kahn, 2010; Oreopoulos, von Wachter, and Heisz, 2012; Altonji, Kahn, and Speer, 2016). This mechanism seems to be operating on white female STEM graduates. The post-IA90 STEM graduates in states with high foreign STEM exposure likely experienced especially difficult early labor market outcomes, and this pushed some white female STEM graduates out of the labor force in the long run.

\section{Conclusion}

Increasing the STEM workforce is vital for national economic performance and individual wellbeing. Meeting the growing demand for STEM workers in the U.S. has been achieved in recent decades largely by increased inflows of foreign-born workers. Furthermore, many businesses, researchers, and policymakers have called for further increases in the foreign STEM workforce, e.g., by "stapling green cards to diplomas" for foreign-born STEM graduates educated in the U.S. (Viser, 2012; Smith, 2015). High-skilled foreigners provide considerable benefits to receiving countries, but may also create unintended consequences by altering the human capital investment and utilization of natives. In particular, growing the foreign STEM workforce may crowd natives out of STEM fields during college and STEM occupations later in their careers. These adverse effects may also be disproportionately felt by women and minorities. 
We examine effects of foreign STEM workers on native STEM education by utilizing the Immigration Act of 1990 as a natural experiment and exploiting both spatial and temporal variation in foreign STEM exposure. We find that IA90 did not significantly reduce STEM education among most groups of natives examined, which is good news. The net effect of IA90 has been to substantially increase the STEM-educated workforce in the U.S., which has fueled innovation and economic growth (Kerr and Lincoln, 2010; Winters, 2014a; Peri, Shih, and Sparber, 2015).

However, we do find that natives with high exposure to foreign STEM workers were on average adversely affected by the policy in three different ways: (1) black males were substantially pushed out of STEM degrees by IA90; (2) white male STEM graduates were less likely to be employed in STEM occupations later in their careers; and (3) white female STEM graduates were less likely to be employed.

Our results suggest that the cohort share of black males completing STEM degrees was substantially reduced by IA90. STEM majors are among the highest paying degree fields, so this displacement of black males is a troubling result. Thus, while increasing the foreign STEM workforce likely benefits the U.S. overall, it imposes substantial costs on black males, so that net gains/losses are not equally distributed. Black males, who are already disadvantaged in the labor market in many dimensions, bear a disproportionate burden.

Similarly, our results suggest welfare losses for white STEM graduates, primarily through the channel of lower earnings due to a reduced ability to find employment in an occupation related to their college major (Kinsler and Pavan, 2015). White female STEM graduates may be especially burdened relative to white males and many respond by permanently exiting the labor force. Black female STEM graduates may also be adversely affected, but our results for them are not precisely estimated. 
We also explicitly examine effects of IA90 on native earnings. Results are imprecisely estimated but are suggestive of some adverse income effects, especially for black male college graduates and black and white female STEM graduates.

Our findings highlight important concerns and implications for policy proposals to further increase the foreign STEM workforce. While there may be broader national benefits of increased STEM inflows, there are important costs as well that are disproportionately borne by natives with high labor market exposure to foreign STEM graduates. Substantially increasing the stock of foreign STEM workers, e.g., by "stapling green cards to diplomas" would likely have unintended consequences that harm some natives. A more balanced approach to high skilled in-migration may be warranted. Furthermore, our results may justify additional policy efforts to shield women and underrepresented minorities from being disproportionately burdened. 


\section{References}

Altonji, Joseph G., Lisa B. Kahn, and Jamin D. Speer. 2016. "Cashier or Consultant? Entry Labor Market Conditions, Field of Study, and Career Success." Journal of Labor Economics 34 (S1):S361-S401.

Arcidiacono, Peter, Esteban M. Aucejo, and V. Joseph Hotz. 2016. "University Differences in the Graduation of Minorities in STEM Fields: Evidence from California." American Economic Review 106 (3):525-562.

Arcidiacono, Peter, Esteban M. Aucejo, and Ken Spenner. 2012. "What Happens after Enrollment? An Analysis of the Time Path of Racial Differences in GPA and Major Choice." IZA Journal of Labor Economics 1 (1):1-24.

Austen-Smith, David and Roland G. Fryer, Jr. 2005. “An Economic Analysis of 'Acting White'." Quarterly Journal of Economics 120 (2):551-583.

Beck, Roy. 1996. The Case Against Immigration. New York: WW Norton.

Bidwell, Allie. 2015. "STEM Workforce No More Diverse than 14 Years Ago." US News \& World Report URL http: //www . usnews . com/news/stem-solutions/articles/2015/02/ 24/stem-workforce-no-more-diverse-than-14-years-ago. Accessed March 23, 2016.

Borjas, George J. 1999. Heaven's Door: Immigration Policy and the American Economy. Princeton, NJ: Princeton University Press.

— 2003. "The Labor Demand Curve is Downward Sloping: Reexamining the Impact of Immigration on the Labor Market." Quarterly Journal of Economics 118 (4):1335-1374.

Borjas, George J., Jeffrey Grogger, and Gordon H. Hanson. 2010. "Immigration and the Economic Status of African-American Men.” Economica 77 (306):255-282.

Bound, John, Breno Braga, Joseph M. Golden, and Gaurav Khanna. 2015. "Recruitment of Foreigners in the Market for Computer Scientists in the United States." Journal of Labor Economics 33 (S1):S187-S223.

Bound, John, Breno Braga, Joseph M. Golden, and Sarah Turner. 2013. "Pathways to Adjustment: The Case of Information Technology Workers." American Economic Review 103 (3):203-207.

Bound, John and Sarah Turner. 2013. "U.S. High-Skill Immigration.” In U.S. 2010: America After the First Decade of the New Century. New York: Russell Sage Foundation.

Card, David. 2001. "Immigrant Inflows, Native Outflows, and the Local Labor Market Impacts of Higher Immigration.” Journal of Labor Economics 19 (1):22-64.

Card, David and Laura Giuliano. 2015. "Can Universal Screening Increase the Representation of Low Income and Minority Students in Gifted Education?" Working Paper 21519, National Bureau of Economic Research. 
Chang, Edward T. 1993. "Los Angeles Riots and Korean-African American Conflict." Korean and Korean-American Studies Bulletin 4 (3):10-11.

Clark, Brian. 2015. "Shocked Out of Your Major: Do Labor Market Shocks Prompt Major Switching?” Working paper, Duke University.

Couch, Kenneth A. and Robert Fairlie. 2010. "Last Hired, First Fired? Black-White Unemployment and the Business Cycle." Demography 47 (1):227-247.

Dynarski, Susan. 2008. "Building the Stock of College-Educated Labor." Journal of Human Resources 43 (3):576-610.

Fryer, Roland G. and Paul Torelli. 2010. "An Empirical Analysis of 'Acting White'." Journal of Public Economics 94 (5):380-396.

Greenwood, Michael J. and Fred A. Ziel. 1997. "The Impact of the Immigration Act of 1990 on US Immigration.” In U.S. Commission on Immigration Reform Research Papers.

Griffith, Amanda L. 2010. "Persistence of Women and Minorities in STEM Field Majors: Is It the School that Matters?” Economics of Education Review 29 (6):911-922.

- 2014. "Faculty Gender in the College Classroom: Does it Matter for Achievement and Major Choice?” Southern Economic Journal 81 (1):211-231.

Hirsch, Barry T. and John V. Winters. 2014. "An Anatomy of Racial and Ethnic Trends in Male Earnings." Review of Income and Wealth 60 (4):930-947.

Hoynes, Hilary, Douglas L. Miller, and Jessamyn Schaller. 2012. "Who Suffers During Recessions?" Journal of Economic Perspectives 26 (3):27-47.

Hunt, Jennifer and Marjolaine Gauthier-Loiselle. 2010. "How Much Does Immigration Boost Innovation?" American Economic Journal: Macroeconomics 2 (2):31-56.

Kahn, Lisa B. 2010. "The Long-Term Labor Market Consequences of Graduating from College in a Bad Economy." Labour Economics 17 (2):303-316.

Kaufman, Jonathan. 1995. "Help Unwanted: Immigrants’ Businesses Often Refuse to Hire Blacks in Inner City." Wall Street Journal URL http: //www. usnews . com/news/stem-solutions/ articles/2015/02/24/stem-workforce-no-more-diverse-than-14-years-ago.

Kerr, William R. 2013. "U.S. High-Skilled Immigration, Innovation, and Entrepreneurship: Empirical Approaches and Evidence.” Working Paper 19377, NBER.

Kerr, William R. and William F. Lincoln. 2010. "The Supply Side of Innovation: H-1B Visa Reforms and U.S. Ethnic Invention.” Journal of Labor Economics 28 (3):473-508.

Kinsler, Josh and Ronni Pavan. 2015. "The Specificity of General Human Capital: Evidence from College Major Choice." Journal of Labor Economics 33 (4):933-972. 
Long, Mark C., Dan Goldhaber, and Nick Huntington-Klein. 2015. "Do Completed College Majors Respond to Changes in Wages?" Economics of Education Review 49 (1):1-14.

Lowe, Gregory, II. 2016. "It's Not Just the Oscars: \#TechSoWhite, Too." USA TODAY URL http://www.usatoday.com/story/tech/columnist/2016/03/09/ gregory-lowe-ii-techsowhite-guest-column/81235276/. Accessed March 23, 2016.

Lowell, B. Lindsay. 2001. "Skilled Temporary and Permanent Immigration to the United States." Population Research and Policy Review 20 (1-2):33-58.

- 2010. “A Long View of America's Immigration Policy and the Supply of Foreign-Born STEM Workers in the United States.” American Behavioral Scientist 53 (7):1029-1044.

Malamud, Ofer and Abigail Wozniak. 2012. "The Impact of College on Migration: Evidence from the Vietnam Generation.” Journal of Human Resources 47 (4):913-950.

National Academies (National Academy of Sciences, National Academy of Engineering, and Institute of Medicine). 2010. Rising Above the Gathering Storm, Revisited: Rapidly Approaching Category 5. Washington, DC: National Academies Press.

National Academy of Sciences. 2007. Beyond Bias and Barriers: Fulfilling the Potential of Women in Academic Science and Engineering. Washington, DC: National Academies Press.

Neate, Rupert. 2015. "Black Politicians to Push Silicon Valley Giants on 'Appalling' Lack of Diversity." The Guardian Accessed March 23, 2016.

Oreopoulos, Philip, Till von Wachter, and Andrew Heisz. 2012. "The Short- and Long-Term Career Effects of Graduating in a Recession." American Economic Journal: Applied Economics $4(1): 1-29$.

Orrenius, Pia M. and Madeline Zavodny. 2015. "Does Immigration Affect Whether US Natives Major in Science and Engineering?” Journal of Labor Economics 33 (S1):S79-S108.

Peri, Giovanni, Kevin Shih, and Chad Sparber. 2015. "STEM Workers, H-1B Visas, and Productivity in US Cities.” Journal of Labor Economics 33 (S1):S225-S255.

Peri, Giovanni and Chad Sparber. 2009. "Task Specialization, Immigration, and Wages.” American Economic Journal: Applied Economics 1 (3):135-169.

—. 2011. "Highly Educated Immigrants and Native Occupational Choice." Industrial Relations 50 (3):385-411.

President Bush, George H.W. 1990. "Statement on Signing the Immigration Act of 1990." The American Presidency Project URL http://www.presidency.ucsb.edu/ws/?pid=19117. Accessed December 19, 2015.

President's Council of Advisors on Science and Technology (PCAST). 2012. Engage to Excel: Producing One Million Additional College Graduates with Degrees in Science, Technology, Engineering, And Mathematics. Washington, DC: Executive Office of the President. 
Price, Joshua. 2010. "The Effect of Instructor Race and Gender on Student Persistence in STEM Fields." Economics of Education Review 29 (6):901-910.

Ruggles, Steven, Katie Genadek, Ronald Goeken, Josiah Grover, and Matthew Sobek. 2015. Integrated Public Use Microdata Series: Version 6.0 [Machine-readable database]. Minneapolis: University of Minnesota.

Sjoquist, David L. and John V. Winters. 2014. "Merit Aid and Post-College Retention in the State." Journal of Urban Economics 80 (1):39-50.

- 2015. "State Merit Aid Programs and College Major: A Focus on STEM." Journal of Labor Economics 33 (4):973-1006.

Smith, Nancy Duvergne. 2015. “'Staple a Green Card to Every Diploma', Slice of MIT URL https://slice.mit.edu/2015/09/24/staple-a-green-card-to-every-diploma/. Accessed March 23, 2016.

Vara, Vauhini. 2016. "Why Doesn’t Silicon Valley Hire Black Coders?” Bloomberg Businessweek Accessed March 23, 2016.

Viser, Matt. 2012. "Mitt Romney Offers Immigration Proposals in Speech Before Latino Group." Boston Globe URL http://archive.boston.com/politicalintelligence/2012/06/ 21/mitt-romney-offers-immigration-proposals-speech-before-latino-group/ jXcGD8wXOIOvgDdophnFyL/story.html. Accessed March 23, 2016.

Waldinger, Roger. 1997. "Black/Immigrant Competition Re-assessed: New Evidence from Los Angeles." Sociological Perspectives 40 (3):365-386.

Weise, Elizabeth and Jessica Guynn. 2014. "Tech Jobs: Minorities Have Degrees, But Don't Get Hired.” USA TODAY Accessed March 23, 2016.

Winters, John V. 2014a. "Foreign and Native-Born STEM Graduates and Innovation Intensity in the United States.” Discussion Paper 8575, IZA.

_. 2014b. "STEM Graduates, Human Capital Externalities, and Wages in the U.S." Regional Science and Urban Economics 48 (1):190-198.

Wiswall, Matthew and Basit Zafar. 2015. "Determinants of College Major Choice: Identification using an Information Experiment.” Review of Economic Studies 82 (2):791-824.

Zafar, Basit. 2011. "How do College Students Form Expectations?" Journal of Labor Economics 29 (2):301-348. 


\section{Figures and Tables}

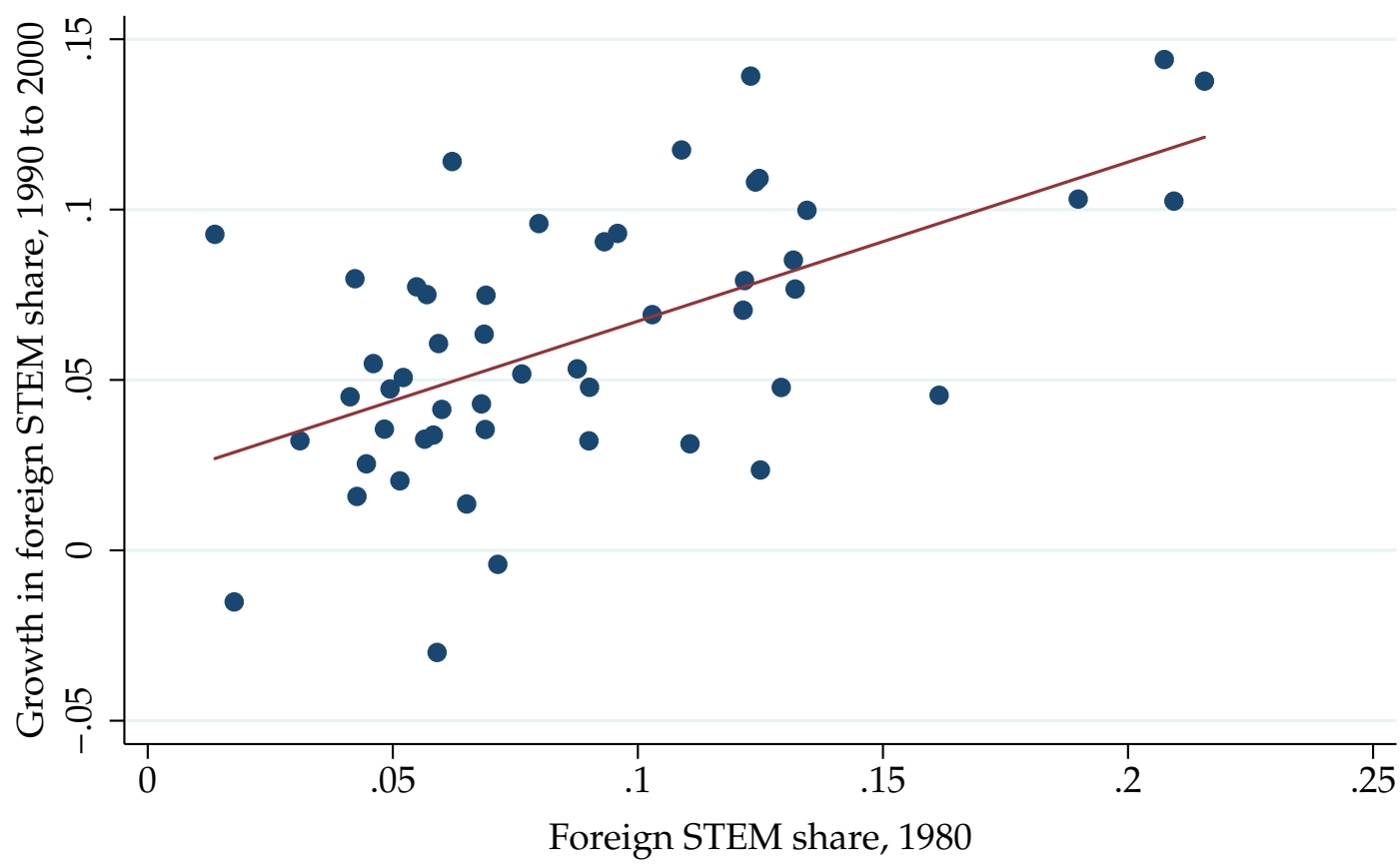

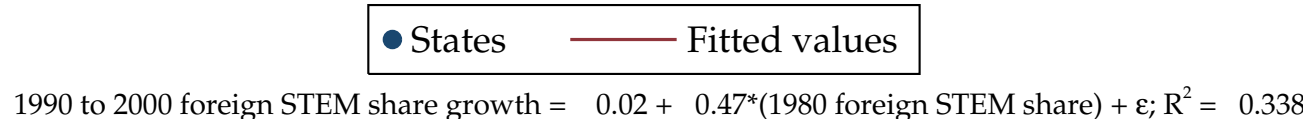

Figure 1: Relationship between Foreign Worker Inflows and 1980 Foreign Worker Shares 
Table 1: Weighted Summary Statistics of Outcome and Explanatory Variables

Panel A: Foreign STEM Exposure Summary Statistics for 1991-1994 Cohorts

\begin{tabular}{lcccc}
\hline & Mean & Std. Dev. & Min & Max \\
\hline Black Males & 0.121 & 0.057 & 0.018 & 0.216 \\
Black Females & 0.121 & 0.057 & 0.018 & 0.216 \\
White Males & 0.118 & 0.057 & 0.018 & 0.216 \\
White Females & 0.118 & 0.057 & 0.018 & 0.216
\end{tabular}

Panel B: Sample Means of Dependent Variables for 1986-1989 Cohorts

\begin{tabular}{|c|c|c|c|c|}
\hline & $\begin{array}{l}\text { Black } \\
\text { Male }\end{array}$ & $\begin{array}{c}\text { Black } \\
\text { Female }\end{array}$ & $\begin{array}{l}\text { White } \\
\text { Male }\end{array}$ & $\begin{array}{l}\text { White } \\
\text { Female }\end{array}$ \\
\hline \multicolumn{5}{|l|}{ Main Education Variables } \\
\hline STEM Degree Unconditional on Education Level & 0.040 & 0.028 & 0.100 & 0.044 \\
\hline Bachelor's Degree Completion in Any Field & 0.163 & 0.236 & 0.345 & 0.387 \\
\hline STEM Degree Conditional on Bachelor's Completion & 0.246 & 0.119 & 0.291 & 0.115 \\
\hline \multicolumn{5}{|l|}{ Recent STEM Occupation } \\
\hline Unconditional on Education Level & 0.027 & 0.014 & 0.063 & 0.018 \\
\hline Conditional on Bachelor's Completion & 0.096 & 0.038 & 0.123 & 0.032 \\
\hline Conditional on Bachelor's in STEM Field & 0.284 & 0.190 & 0.301 & 0.145 \\
\hline Conditional on Bachelor's in Non-STEM Field & 0.035 & 0.018 & 0.050 & 0.018 \\
\hline \multicolumn{5}{|l|}{ Current STEM Employment } \\
\hline Unconditional on Education Level & 0.025 & 0.013 & 0.060 & 0.016 \\
\hline Conditional on Bachelor's Completion & 0.090 & 0.035 & 0.119 & 0.029 \\
\hline Conditional on Bachelor's in STEM Field & 0.268 & 0.169 & 0.292 & 0.132 \\
\hline Conditional on Bachelor's in Non-STEM Field & 0.031 & 0.017 & 0.048 & 0.016 \\
\hline \multicolumn{5}{|l|}{ Any Current Employment } \\
\hline Unconditional on Education Level & 0.656 & 0.713 & 0.842 & 0.734 \\
\hline Conditional on Bachelor's Completion & 0.892 & 0.874 & 0.937 & 0.801 \\
\hline Conditional on Bachelor's in STEM Field & 0.886 & 0.878 & 0.946 & 0.817 \\
\hline Conditional on Bachelor's in Non-STEM Field & 0.894 & 0.873 & 0.934 & 0.799 \\
\hline \multicolumn{5}{|l|}{ Prior Year Employment } \\
\hline Unconditional on Education Level & 0.741 & 0.774 & 0.896 & 0.790 \\
\hline Conditional on Bachelor's Completion & 0.929 & 0.916 & 0.965 & 0.849 \\
\hline Conditional on Bachelor's in STEM Field & 0.920 & 0.927 & 0.968 & 0.858 \\
\hline Conditional on Bachelor's in Non-STEM Field & 0.932 & 0.914 & 0.964 & 0.848 \\
\hline \multicolumn{5}{|l|}{ Prior Year Log Earnings } \\
\hline Unconditional on Education Level & 10.26 & 10.14 & 10.75 & 10.22 \\
\hline Conditional on Bachelor's Completion & 10.91 & 10.65 & 11.24 & 10.58 \\
\hline Conditional on Bachelor's in STEM Field & 11.11 & 10.85 & 11.38 & 10.83 \\
\hline Conditional on Bachelor's in Non-STEM Field & 10.85 & 10.63 & 11.19 & 10.55 \\
\hline
\end{tabular}

Note: By definition, the measures of foreign STEM exposure in panel A all equal zero for the 1986-1989 cohorts. The reported means in panel B are used to quantify the magnitudes of the effects that we examine. 
Table 2: Effects of Birth-State Foreign STEM Exposure on STEM Degree Completion

\begin{tabular}{lcccc}
\hline & $\begin{array}{c}\text { Black } \\
\text { Male }\end{array}$ & $\begin{array}{c}\text { Black } \\
\text { Female }\end{array}$ & $\begin{array}{c}\text { White } \\
\text { Male }\end{array}$ & $\begin{array}{c}\text { White } \\
\text { Female }\end{array}$ \\
\hline Foreign STEM Exposure & $-0.241 * * *$ & -0.013 & -0.015 & 0.032 \\
& $(0.074)$ & $(0.048)$ & $(0.047)$ & $(0.026)$ \\
Demographic characteristics & $\checkmark$ & $\checkmark$ & $\checkmark$ & $\checkmark$ \\
State characteristics & $\checkmark$ & $\checkmark$ & $\checkmark$ & $\checkmark$ \\
State trends & $\checkmark$ & $\checkmark$ & $\checkmark$ & $\checkmark$ \\
\hline$N$ & 70,671 & 77,524 & 512,625 & 515,610 \\
\hline
\end{tabular}

Notes: Dependent variable is an indicator for graduating in a STEM field, unconditional on education level. Each coefficient is estimated from a different linear probability model. Foreign STEM Exposure is measured at the birth state level as an interaction term between the year 1980 share of STEM workers who are foreign born in one's birth state and a dummy for cohorts reaching age 18 in 1991 and later, as defined in Equation (2). The regression sample comes from the 2009-2014 American Community Survey and includes persons who were age 18 in 1986-1994, excluding 1990. Demographic characteristics include dummy variable controls for birth state, year age 18, age, and survey year. Timevarying state controls include log cohort size, the state unemployment rate, and log median household income measured for an individual's birth state in the year they were age 18 . State trends include birth-state-specific linear trends for year age 18. Standard errors in parentheses are clustered by birth state. ***Significantly different from zero at the $1 \%$ level.

Table 3: Effects of Foreign STEM Exposure on Overall Bachelor's Degree Attainment

\begin{tabular}{lcccc}
\hline & $\begin{array}{c}\text { Black } \\
\text { Male }\end{array}$ & $\begin{array}{c}\text { Black } \\
\text { Female }\end{array}$ & $\begin{array}{c}\text { White } \\
\text { Male }\end{array}$ & $\begin{array}{c}\text { White } \\
\text { Female }\end{array}$ \\
\hline Foreign STEM Exposure & 0.013 & -0.027 & 0.051 & -0.083 \\
& $(0.130)$ & $(0.156)$ & $(0.063)$ & $(0.067)$ \\
Demographic characteristics & $\checkmark$ & $\checkmark$ & $\checkmark$ & $\checkmark$ \\
State characteristics & $\checkmark$ & $\checkmark$ & $\checkmark$ & $\checkmark$ \\
State trends & $\checkmark$ & $\checkmark$ & $\checkmark$ & $\checkmark$ \\
\hline$N$ & 70,671 & 77,524 & 512,625 & 515,610 \\
\hline
\end{tabular}

Notes: Dependent variable is an indicator for graduating college, unconditional on education level. Each coefficient is estimated from a different linear probability model. Foreign STEM Exposure is measured at the birth state level as an interaction term between the year 1980 share of STEM workers who are foreign born in one's birth state and a dummy for cohorts reaching age 18 in 1991 and later, as defined in Equation (2). The regression sample comes from the 2009-2014 American Community Survey and includes persons who were age 18 in 1986-1994, excluding 1990. Demographic characteristics include dummy variable controls for birth state, year age 18, age, and survey year. Time-varying state controls include log cohort size, the state unemployment rate, and log median household income measured for an individual's birth state in the year they were age 18. State trends include birth-state-specific linear trends for year age 18. Standard errors in parentheses are clustered by birth state. 
Table 4: Effects of Foreign STEM Exposure on STEM Degree Conditional on Bachelor's Completion

\begin{tabular}{lcccc}
\hline & $\begin{array}{c}\text { Black } \\
\text { Male }\end{array}$ & $\begin{array}{c}\text { Black } \\
\text { Female }\end{array}$ & $\begin{array}{c}\text { White } \\
\text { Male }\end{array}$ & $\begin{array}{c}\text { White } \\
\text { Female }\end{array}$ \\
\hline Foreign STEM Exposure & $-1.377 * * *$ & -0.041 & -0.114 & 0.073 \\
& $(0.324)$ & $(0.231)$ & $(0.130)$ & $(0.062)$ \\
Demographic characteristics & $\checkmark$ & $\checkmark$ & $\checkmark$ & $\checkmark$ \\
State characteristics & $\checkmark$ & $\checkmark$ & $\checkmark$ & $\checkmark$ \\
State trends & $\checkmark$ & $\checkmark$ & $\checkmark$ & $\checkmark$ \\
\hline$N$ & 10,650 & 19,413 & 179,134 & 210,459 \\
\hline
\end{tabular}

Notes: Dependent variable is an indicator for graduating with a STEM major, conditional on college graduation. Each coefficient is estimated from a different linear probability model. Foreign STEM Exposure is measured at the birth state level as an interaction term between the year 1980 share of STEM workers who are foreign born in one's birth state and a dummy for cohorts reaching age 18 in 1991 and later, as defined in Equation (2). The regression sample comes from the 2009-2014 American Community Survey and includes persons who were age 18 in 1986-1994, excluding 1990. Demographic characteristics include dummy variable controls for birth state, year age 18, age, and survey year. Timevarying state controls include log cohort size, the state unemployment rate, and log median household income measured for an individual's birth state in the year they were age 18 . State trends include birth-state-specific linear trends for year age 18. Standard errors in parentheses are clustered by birth state. ***Significantly different from zero at the $1 \%$ level.

Table 5: Effects of Foreign STEM Exposure on Non-STEM Degree Completion for Black Males

\begin{tabular}{lcccccc}
\hline & & & & Liberal & Social & Other \\
& Business & Education & Health & Arts & Sciences & Majors \\
\hline Foreign STEM Exposure & 0.078 & 0.016 & 0.031 & 0.062 & 0.041 & 0.027 \\
& $(0.073)$ & $(0.047)$ & $(0.028)$ & $(0.066)$ & $(0.077)$ & $(0.026)$ \\
Demographic characteristics & $\checkmark$ & $\checkmark$ & $\checkmark$ & $\checkmark$ & $\checkmark$ & $\checkmark$ \\
State characteristics & $\checkmark$ & $\checkmark$ & $\checkmark$ & $\checkmark$ & $\checkmark$ & $\checkmark$ \\
State trends & $\checkmark$ & $\checkmark$ & $\checkmark$ & $\checkmark$ & $\checkmark$ & $\checkmark$ \\
\hline$N$ & 70,671 & 70,671 & 70,671 & 70,671 & 70,671 & 70,671 \\
\hline
\end{tabular}

Notes: Dependent variable is an indicator for graduating with a given non-STEM major, unconditional on education level. Each coefficient is estimated from a different linear probability model. Foreign STEM Exposure is measured at the birth state level as an interaction term between the year 1980 share of STEM workers who are foreign born in one's birth state and a dummy for cohorts reaching age 18 in 1991 and later, as defined in Equation (2). The regression sample comes from the 2009-2014 American Community Survey and includes persons who were age 18 in 1986-1994, excluding 1990. Demographic characteristics include dummy variable controls for birth state, year age 18, age, and survey year. Time-varying state controls include log cohort size, the state unemployment rate, and $\log$ median household income measured for an individual's birth state in the year they were age 18. State trends include birth-state-specific linear trends for year age 18. Standard errors in parentheses are clustered by birth state. 
Table 6: Effects of Foreign STEM Exposure on STEM Degree Sub-fields for Black Males

\begin{tabular}{lccccccc}
\hline & Computer & & & Biological & Physical & \multicolumn{2}{c}{ All Other } \\
& Science & Engineering & Technology & Sciences & Sciences & Mathematics & STEM \\
\hline Foreign STEM Exposure & -0.039 & -0.024 & -0.014 & -0.063 & -0.030 & $-0.039 * *$ & -0.033 \\
& $(0.029)$ & $(0.036)$ & $(0.016)$ & $(0.041)$ & $(0.024)$ & $(0.016)$ & $(0.032)$ \\
Demographic characteristics & $\checkmark$ & $\checkmark$ & $\checkmark$ & $\checkmark$ & $\checkmark$ & $\checkmark$ & $\checkmark$ \\
State characteristics & $\checkmark$ & $\checkmark$ & $\checkmark$ & $\checkmark$ & $\checkmark$ & $\checkmark$ & $\checkmark$ \\
State trends & $\checkmark$ & $\checkmark$ & $\checkmark$ & $\checkmark$ & $\checkmark$ & $\checkmark$ & $\checkmark$ \\
\hline$N$ & 70,671 & 70,671 & 70,671 & 70,671 & 70,671 & 70,671 & 70,671 \\
\hline
\end{tabular}

Notes: Dependent variable is an indicator for graduating with a given STEM major, unconditional on education level. Each coefficient is estimated from a different linear probability model. Foreign STEM Exposure is measured at the birth state level as an interaction term between the year 1980 share of STEM workers who are foreign born in one's birth state and a dummy for cohorts reaching age 18 in 1991 and later, as defined in Equation (2). The regression sample comes from the 2009-2014 American Community Survey and includes persons who were age 18 in 1986-1994, excluding 1990. Demographic characteristics include dummy variable controls for birth state, year age 18, age, and survey year. Time-varying state controls include log cohort size, the state unemployment rate, and log median household income measured for an individual's birth state in the year they were age 18. State trends include birth-state-specific linear trends for year age 18. Standard errors in parentheses are clustered by birth state. **Significantly different from zero at the 5\% level. 
Table 7: Effects of Birth-State Foreign STEM Exposure on STEM Degree Completion by Birth Cohort

\begin{tabular}{|c|c|c|c|c|}
\hline & $\begin{array}{l}\text { Black } \\
\text { Male }\end{array}$ & $\begin{array}{c}\text { Black } \\
\text { Female }\end{array}$ & $\begin{array}{l}\text { White } \\
\text { Male }\end{array}$ & $\begin{array}{l}\text { White } \\
\text { Female }\end{array}$ \\
\hline Foreign STEM Exposure $\times 1$ [year age $18=1986]$ & $\begin{array}{l}-0.075 \\
(0.076)\end{array}$ & $\begin{array}{c}0.034 \\
(0.059)\end{array}$ & $\begin{array}{l}-0.051 * \\
(0.028)\end{array}$ & $\begin{array}{l}-0.023 \\
(0.017)\end{array}$ \\
\hline Foreign STEM Exposure $\times 1$ [year age $18=1987]$ & $\begin{array}{l}-0.021 \\
(0.087)\end{array}$ & $\begin{array}{l}-0.026 \\
(0.068)\end{array}$ & $\begin{array}{l}-0.005 \\
(0.028)\end{array}$ & $\begin{array}{c}-0.035 * \\
(0.018)\end{array}$ \\
\hline Foreign STEM Exposure $\times 1$ [year age $18=1988]$ & $\begin{array}{c}0.025 \\
(0.050)\end{array}$ & $\begin{array}{c}0.013 \\
(0.058)\end{array}$ & $\begin{array}{l}-0.010 \\
(0.024)\end{array}$ & $\begin{array}{c}0.001 \\
(0.026)\end{array}$ \\
\hline Foreign STEM Exposure $\times 1$ [year age $18=1989]$ & $\begin{array}{l}-0.006 \\
(0.083)\end{array}$ & $\begin{array}{c}0.035 \\
(0.081)\end{array}$ & $\begin{array}{l}-0.028 \\
(0.033)\end{array}$ & $\begin{array}{c}-0.052 * * \\
(0.020)\end{array}$ \\
\hline Foreign STEM Exposure $\times 1$ [year age $18=1990]$ & $\begin{array}{c}\text { omitted } \\
\text { (base cohort) }\end{array}$ & $\begin{array}{c}\text { omitted } \\
\text { (base cohort) }\end{array}$ & $\begin{array}{c}\text { omitted } \\
\text { (base cohort) }\end{array}$ & $\begin{array}{c}\text { omitted } \\
\text { (base cohort) }\end{array}$ \\
\hline Foreign STEM Exposure $\times 1$ [year age $18=1991]$ & $\begin{array}{c}-0.162 * \\
(0.083)\end{array}$ & $\begin{array}{c}0.002 \\
(0.060)\end{array}$ & $\begin{array}{l}-0.036 \\
(0.030)\end{array}$ & $\begin{array}{l}-0.006 \\
(0.020)\end{array}$ \\
\hline Foreign STEM Exposure $\times 1$ [year age $18=1992]$ & $\begin{array}{l}-0.120 \\
(0.106)\end{array}$ & $\begin{array}{c}0.050 \\
(0.064)\end{array}$ & $\begin{array}{c}0.031 \\
(0.040)\end{array}$ & $\begin{array}{l}-0.013 \\
(0.024)\end{array}$ \\
\hline Foreign STEM Exposure $\times 1$ [year age $18=1993$ ] & $\begin{array}{l}-0.144 \\
(0.095)\end{array}$ & $\begin{array}{c}0.006 \\
(0.073)\end{array}$ & $\begin{array}{l}-0.023 \\
(0.035)\end{array}$ & $\begin{array}{c}0.002 \\
(0.024)\end{array}$ \\
\hline Foreign STEM Exposure $\times 1$ [year age $18=1994]$ & $\begin{array}{l}-0.095 \\
(0.064)\end{array}$ & $\begin{array}{c}0.033 \\
(0.077)\end{array}$ & $\begin{array}{c}0.022 \\
(0.022)\end{array}$ & $\begin{array}{l}-0.009 \\
(0.035)\end{array}$ \\
\hline $\begin{array}{l}\text { Demographic characteristics } \\
\text { Time-varying State controls } \\
\text { State-specific year age } 18 \text { trends }\end{array}$ & $\begin{array}{l}\checkmark \\
\checkmark\end{array}$ & $\begin{array}{l}\checkmark \\
\checkmark\end{array}$ & $\begin{array}{l}\checkmark \\
\checkmark\end{array}$ & $\begin{array}{l}\checkmark \\
\checkmark\end{array}$ \\
\hline$N$ & 79,494 & 87,428 & 576,513 & 580,348 \\
\hline
\end{tabular}

Notes: Dependent variable is an indicator for graduating in a STEM field, unconditional on education level. Each column is estimated from a different linear probability model. Foreign STEM Exposure is measured as defined in Equation (2) and interacted with birth cohort dummies. The regression sample comes from the 2009-2014 American Community Survey and includes persons who were age 18 in 1986-1994, excluding 1990. Demographic characteristics include dummy variable controls for birth state, year age 18, age, and survey year. Time-varying state controls include log cohort size, the state unemployment rate, and log median household income measured for an individual's birth state in the year they were age 18. State trends are excluded. Standard errors in parentheses are clustered by birth state. *Significantly different from zero at the $10 \%$ level; **Significant at $5 \%$ level. 
Table 8: Effects of Birth-State Foreign STEM Exposure on Recently Holding a STEM Occupation

\begin{tabular}{|c|c|c|c|c|}
\hline & $\begin{array}{l}\text { Black } \\
\text { Male }\end{array}$ & $\begin{array}{c}\text { Black } \\
\text { Female }\end{array}$ & $\begin{array}{l}\text { White } \\
\text { Male }\end{array}$ & $\begin{array}{l}\text { White } \\
\text { Female }\end{array}$ \\
\hline \multicolumn{5}{|c|}{ Panel A: Unconditional on education level } \\
\hline Foreign STEM Exposure & $\begin{array}{c}-0.002 \\
(0.063)\end{array}$ & $\begin{array}{c}0.013 \\
(0.056)\end{array}$ & $\begin{array}{c}-0.075 * * * \\
(0.024)\end{array}$ & $\begin{array}{c}-0.004 \\
(0.017)\end{array}$ \\
\hline$N$ & 70,671 & 77,524 & 512,625 & 515,610 \\
\hline \multicolumn{5}{|c|}{ Panel B: Conditional on college graduation in any field } \\
\hline Foreign STEM Exposure & $\begin{array}{c}-0.079 \\
(0.300)\end{array}$ & $\begin{array}{c}0.106 \\
(0.192)\end{array}$ & $\begin{array}{c}-0.255 * * * \\
(0.067)\end{array}$ & $\begin{array}{c}-0.007 \\
(0.032)\end{array}$ \\
\hline$N$ & 10,650 & 19,413 & 179,134 & 210,459 \\
\hline \multicolumn{5}{|c|}{ Panel C: Conditional on college graduation in a STEM field } \\
\hline Foreign STEM Exposure & $\begin{array}{c}0.367 \\
(0.825)\end{array}$ & $\begin{array}{l}-0.292 \\
(0.963)\end{array}$ & $\begin{array}{c}-0.681 * * * \\
(0.158)\end{array}$ & $\begin{array}{r}-0.374 * * \\
(0.186)\end{array}$ \\
\hline$N$ & 2,720 & 2,593 & 53,848 & 27,040 \\
\hline \multicolumn{5}{|c|}{ Panel D: Conditional on college graduation in a non-STEM field } \\
\hline Foreign STEM Exposure & $\begin{array}{c}0.138 \\
(0.198)\end{array}$ & $\begin{array}{c}0.137 \\
(0.086)\end{array}$ & $\begin{array}{c}-0.062 \\
(0.049)\end{array}$ & $\begin{array}{c}0.033 \\
(0.022)\end{array}$ \\
\hline$N$ & 7,930 & 16,820 & 125,286 & 183,419 \\
\hline
\end{tabular}

Notes: Dependent variable is an indicator for most recent occupation being in a STEM field. Each coefficient is estimated from a different linear probability model. Foreign STEM Exposure is measured at the birth state level as an interaction term between the year 1980 share of STEM workers who are foreign born in one's birth state and a dummy for cohorts reaching age 18 in 1991 and later, as defined in Equation (2). The regression sample comes from the 2009-2014 American Community Survey and includes persons who were age 18 in 1986-1994, excluding 1990. Demographic characteristics include dummy variable controls for birth state, year age 18, age, and survey year. Time-varying state controls include log cohort size, the state unemployment rate, and $\log$ median household income measured for an individual's birth state in the year they were age 18. State trends include birth-state-specific linear trends for year age 18. Standard errors in parentheses are clustered by birth state. ${ }^{* *}$ Significantly different from zero at the $5 \%$ level; ***Significant at $1 \%$ level. 
Table 9: Effects of Birth-State Foreign STEM Exposure on Current Employment in a STEM Occupation

\begin{tabular}{|c|c|c|c|c|}
\hline & $\begin{array}{l}\text { Black } \\
\text { Male }\end{array}$ & $\begin{array}{c}\text { Black } \\
\text { Female }\end{array}$ & $\begin{array}{l}\text { White } \\
\text { Male }\end{array}$ & $\begin{array}{l}\text { White } \\
\text { Female }\end{array}$ \\
\hline \multicolumn{5}{|c|}{ Panel A: Unconditional on education level } \\
\hline Foreign STEM Exposure & $\begin{array}{c}0.009 \\
(0.064)\end{array}$ & $\begin{array}{c}0.016 \\
(0.055)\end{array}$ & $\begin{array}{c}-0.075^{* * * *} \\
(0.024)\end{array}$ & $\begin{array}{l}-0.010 \\
(0.017)\end{array}$ \\
\hline$N$ & 70,671 & 77,524 & 512,625 & 515,610 \\
\hline \multicolumn{5}{|c|}{ Panel B: Conditional on college graduation in any field } \\
\hline Foreign STEM Exposure & $\begin{array}{l}-0.005 \\
(0.298)\end{array}$ & $\begin{array}{c}0.106 \\
(0.175)\end{array}$ & $\begin{array}{c}-0.244 * * * \\
(0.065)\end{array}$ & $\begin{array}{l}-0.001 \\
(0.032)\end{array}$ \\
\hline$N$ & 10,650 & 19,413 & 179,134 & 210,459 \\
\hline \multicolumn{5}{|c|}{ Panel C: Conditional on college graduation in a STEM field } \\
\hline Foreign STEM Exposure & $\begin{array}{c}0.687 \\
(0.897)\end{array}$ & $\begin{array}{l}-0.068 \\
(0.973)\end{array}$ & $\begin{array}{c}-0.643 * * * \\
(0.162)\end{array}$ & $\begin{array}{l}-0.370^{*} \\
(0.186)\end{array}$ \\
\hline$N$ & 2,720 & 2,593 & 53,848 & 27,040 \\
\hline \multicolumn{5}{|c|}{ Panel D: Conditional on college graduation in a non-STEM field } \\
\hline Foreign STEM Exposure & $\begin{array}{c}0.103 \\
(0.201)\end{array}$ & $\begin{array}{c}0.111 \\
(0.077)\end{array}$ & $\begin{array}{l}-0.058 \\
(0.049)\end{array}$ & $\begin{array}{c}0.043 \\
(0.025)\end{array}$ \\
\hline$N$ & 7,930 & 16,820 & 125,286 & 183,419 \\
\hline
\end{tabular}

Notes: Dependent variable is an indicator for current occupation being in a STEM field. Each coefficient is estimated from a different linear probability model. Foreign STEM Exposure is measured at the birth state level as an interaction term between the year 1980 share of STEM workers who are foreign born in one's birth state and a dummy for cohorts reaching age 18 in 1991 and later, as defined in Equation (2). The regression sample comes from the 2009-2014 American Community Survey and includes persons who were age 18 in 1986-1994, excluding 1990. Demographic characteristics include dummy variable controls for birth state, year age 18, age, and survey year. Time-varying state controls include log cohort size, the state unemployment rate, and log median household income measured for an individual's birth state in the year they were age 18. State trends include birth-state-specific linear trends for year age 18 . Standard errors in parentheses are clustered by birth state. *Significantly different from zero at the $10 \%$ level; ***Significant at $1 \%$ level. 
Table 10: Effects of Birth-State Foreign STEM Exposure on Employment Probability

\begin{tabular}{|c|c|c|c|c|}
\hline & $\begin{array}{l}\text { Black } \\
\text { Male }\end{array}$ & $\begin{array}{c}\text { Black } \\
\text { Female }\end{array}$ & $\begin{array}{l}\text { White } \\
\text { Male }\end{array}$ & $\begin{array}{l}\text { White } \\
\text { Female }\end{array}$ \\
\hline \multicolumn{5}{|c|}{ Panel A: Unconditional on education level } \\
\hline Foreign STEM Exposure & $\begin{array}{l}0.398 * \\
(0.202)\end{array}$ & $\begin{array}{c}-0.377 * * \\
(0.174)\end{array}$ & $\begin{array}{c}-0.038 \\
(0.040)\end{array}$ & $\begin{array}{c}-0.037 \\
(0.071)\end{array}$ \\
\hline$N$ & 70,671 & 77,524 & 512,625 & 515,610 \\
\hline \multicolumn{5}{|c|}{ Panel B: Conditional on college graduation in any field } \\
\hline Foreign STEM Exposure & $\begin{array}{c}0.364 \\
(0.287)\end{array}$ & $\begin{array}{c}0.033 \\
(0.276)\end{array}$ & $\begin{array}{c}-0.012 \\
(0.038)\end{array}$ & $\begin{array}{c}-0.107 \\
(0.108)\end{array}$ \\
\hline$N$ & 10,650 & 19,413 & 179,134 & 210,459 \\
\hline \multicolumn{5}{|c|}{ Panel C: Conditional on college graduation in a STEM field } \\
\hline Foreign STEM Exposure & $\begin{array}{c}1.158 \\
(0.814)\end{array}$ & $\begin{array}{l}-0.912 \\
(0.698)\end{array}$ & $\begin{array}{c}-0.174^{*} \\
(0.103)\end{array}$ & $\begin{array}{c}-0.417 * * \\
(0.207)\end{array}$ \\
\hline$N$ & 2,720 & 2,593 & 53,848 & 27,040 \\
\hline \multicolumn{5}{|c|}{ Panel D: Conditional on college graduation in a non-STEM field } \\
\hline Foreign STEM Exposure & $\begin{array}{c}0.082 \\
(0.263)\end{array}$ & $\begin{array}{c}0.172 \\
(0.259)\end{array}$ & $\begin{array}{c}0.063 \\
(0.059)\end{array}$ & $\begin{array}{l}-0.062 \\
(0.106)\end{array}$ \\
\hline$N$ & 7,930 & 16,820 & 125,286 & 183,419 \\
\hline
\end{tabular}

Notes: Dependent variable is an indicator for being employed during the week prior to the survey. Each coefficient is estimated from a different linear probability model. Foreign STEM Exposure is measured at the birth state level as an interaction term between the year 1980 share of STEM workers who are foreign born in one's birth state and a dummy for cohorts reaching age 18 in 1991 and later, as defined in Equation (2). The regression sample comes from the 2009-2014 American Community Survey and includes persons who were age 18 in 1986-1994, excluding 1990. Demographic characteristics include dummy variable controls for birth state, year age 18, age, and survey year. Time-varying state controls include log cohort size, the state unemployment rate, and log median household income measured for an individual's birth state in the year they were age 18. State trends include birth-state-specific linear trends for year age 18 . Standard errors in parentheses are clustered by birth state. *Significantly different from zero at the $10 \%$ level; $* *$ Significant at $5 \%$ level. 
Table 11: Effects of Birth-State Foreign STEM Exposure on Prior Year Employment Probability

\begin{tabular}{|c|c|c|c|c|}
\hline & $\begin{array}{l}\text { Black } \\
\text { Male }\end{array}$ & $\begin{array}{c}\text { Black } \\
\text { Female }\end{array}$ & $\begin{array}{l}\text { White } \\
\text { Male }\end{array}$ & $\begin{array}{l}\text { White } \\
\text { Female }\end{array}$ \\
\hline \multicolumn{5}{|c|}{ Panel A: Unconditional on education level } \\
\hline \multirow[t]{2}{*}{ Foreign STEM Exposure } & $0.258 *$ & $-0.332 *$ & 0.042 & 0.017 \\
\hline & $(0.142)$ & $(0.197)$ & $(0.038)$ & $(0.064)$ \\
\hline$N$ & 70,671 & 77,524 & 512,625 & 515,610 \\
\hline \multicolumn{5}{|c|}{ Panel B: Conditional on college graduation in any field } \\
\hline \multirow[t]{2}{*}{ Foreign STEM Exposure } & $0.505^{*}$ & $0.294 * *$ & 0.076 & -0.069 \\
\hline & $(0.251)$ & $(0.141)$ & $(0.046)$ & $(0.079)$ \\
\hline$N$ & 10,650 & 19,413 & 179,134 & 210,459 \\
\hline \multicolumn{5}{|c|}{ Panel C: Conditional on college graduation in a STEM field } \\
\hline \multirow[t]{2}{*}{ Foreign STEM Exposure } & 0.708 & -0.431 & -0.028 & $-0.400 * *$ \\
\hline & $(0.764)$ & $(0.456)$ & $(0.065)$ & $(0.191)$ \\
\hline$N$ & 2,720 & 2,593 & 53,848 & 27,040 \\
\hline \multicolumn{5}{|c|}{ Panel D: Conditional on college graduation in a non-STEM field } \\
\hline \multirow[t]{2}{*}{ Foreign STEM Exposure } & $0.438 *$ & $0.398 * * *$ & $0.126 * *$ & -0.022 \\
\hline & $(0.241)$ & $(0.136)$ & $(0.059)$ & $(0.081)$ \\
\hline$N$ & 7,930 & 16,820 & 125,286 & 183,419 \\
\hline
\end{tabular}

Notes: Dependent variable is an indicator for being employed at all during the year prior to the survey. Each coefficient is estimated from a different linear probability model. Foreign STEM Exposure is measured at the birth state level as an interaction term between the year 1980 share of STEM workers who are foreign born in one's birth state and a dummy for cohorts reaching age 18 in 1991 and later, as defined in Equation (2). The regression sample comes from the 2009-2014 American Community Survey and includes persons who were age 18 in 1986-1994, excluding 1990. Demographic characteristics include dummy variable controls for birth state, year age 18 , age, and survey year. Time-varying state controls include log cohort size, the state unemployment rate, and log median household income measured for an individual's birth state in the year they were age 18. State trends include birth-state-specific linear trends for year age 18. Standard errors in parentheses are clustered by birth state. *Significantly different from zero at the $10 \%$ level; **Significant at $5 \%$ level; ***Significant at $1 \%$ level. 
Table 12: Effects of Birth-State Foreign STEM Exposure on Log Earnings

\begin{tabular}{|c|c|c|c|c|}
\hline & $\begin{array}{l}\text { Black } \\
\text { Male }\end{array}$ & $\begin{array}{c}\text { Black } \\
\text { Female }\end{array}$ & $\begin{array}{l}\text { White } \\
\text { Male }\end{array}$ & $\begin{array}{l}\text { White } \\
\text { Female }\end{array}$ \\
\hline \multicolumn{5}{|c|}{ Panel A: Unconditional on education level } \\
\hline Foreign STEM Exposure & $\begin{array}{c}-0.518 \\
(0.439)\end{array}$ & $\begin{array}{l}-0.122 \\
(0.506)\end{array}$ & $\begin{array}{c}-0.128 \\
(0.156)\end{array}$ & $\begin{array}{l}-0.228 \\
(0.162)\end{array}$ \\
\hline$N$ & 48,582 & 59,877 & 460,537 & 407,457 \\
\hline \multicolumn{5}{|c|}{ Panel B: Conditional on college graduation in any field } \\
\hline Foreign STEM Exposure & $\begin{array}{c}-1.543^{*} \\
(0.819)\end{array}$ & $\begin{array}{c}0.097 \\
(0.837)\end{array}$ & $\begin{array}{c}-0.296 \\
(0.300)\end{array}$ & $\begin{array}{c}-0.103 \\
(0.222)\end{array}$ \\
\hline$N$ & 9,882 & 17,789 & 173,629 & 178,956 \\
\hline \multicolumn{5}{|c|}{ Panel C: Conditional on college graduation in a STEM field } \\
\hline Foreign STEM Exposure & $\begin{array}{c}-1.544 \\
(1.048)\end{array}$ & $\begin{array}{c}-1.503 \\
(0.992)\end{array}$ & $\begin{array}{c}-0.376 \\
(0.354)\end{array}$ & $\begin{array}{c}-1.058 \\
(0.676)\end{array}$ \\
\hline$N$ & 2,519 & 2,378 & 52,450 & 23,422 \\
\hline \multicolumn{5}{|c|}{ Panel D: Conditional on college graduation in a non-STEM field } \\
\hline Foreign STEM Exposure & $\begin{array}{c}-1.096 \\
(1.051)\end{array}$ & $\begin{array}{c}0.377 \\
(1.011)\end{array}$ & $\begin{array}{l}-0.202 \\
(0.322)\end{array}$ & $\begin{array}{c}0.048 \\
(0.270)\end{array}$ \\
\hline$N$ & 7,363 & 15,411 & 121,179 & 155,534 \\
\hline
\end{tabular}

Notes: Dependent variable is the log of total earned income from the year prior to the survey. Each coefficient is estimated from a different regression model. Foreign STEM Exposure is measured at the birth state level as an interaction term between the year 1980 share of STEM workers who are foreign born in one's birth state and a dummy for cohorts reaching age 18 in 1991 and later, as defined in Equation (2). The regression sample comes from the 2009-2014 American Community Survey and includes persons who were age 18 in 1986-1994, excluding 1990. Demographic characteristics include dummy variable controls for birth state, year age 18 , age, and survey year. Time-varying state controls include log cohort size, the state unemployment rate, and log median household income measured for an individual's birth state in the year they were age 18. State trends include birth-statespecific linear trends for year age 18. Standard errors in parentheses are clustered by birth state. *Significantly different from zero at the $10 \%$ level. 
Table A1: List of STEM Majors and ACS codes

\begin{tabular}{|c|c|c|c|}
\hline ACS code & Description & ACS code & Description \\
\hline 1103 & Animal Sciences & 2504 & Mechanical Engineering Related Technologies \\
\hline 1104 & Food Science & 2599 & Miscellaneous Engineering Technologies \\
\hline 1105 & Plant Science and Agronomy & 3600 & Biology \\
\hline 1106 & Soil Science & 3601 & Biochemical Sciences \\
\hline 1301 & Environmental Science & 3602 & Botany \\
\hline 1302 & Forestry & 3603 & Molecular Biology \\
\hline 2001 & Communication Technologies & 3604 & Ecology \\
\hline 2100 & Computer and Information Systems & 3605 & Genetics \\
\hline 2101 & Computer Programming and Data Processing & 3606 & Microbiology \\
\hline 2102 & Computer Science & 3607 & Pharmacology \\
\hline 2105 & Information Sciences & 3608 & Physiology \\
\hline 2106 & Computer Information Management \& Security & 3609 & Zoology \\
\hline 2107 & Computer Networking and Telecommunications & 3611 & Neuroscience \\
\hline 2400 & General Engineering & 3699 & Miscellaneous Biology \\
\hline 2401 & Aerospace Engineering & 3700 & Mathematics \\
\hline 2402 & Biological Engineering & 3701 & Applied Mathematics \\
\hline 2403 & Architectural Engineering & 3702 & Statistics and Decision Science \\
\hline 2404 & Biomedical Engineering & 3801 & Military Technologies \\
\hline 2405 & Chemical Engineering & 4002 & Nutrition Sciences \\
\hline 2406 & Civil Engineering & 4003 & Neuroscience \\
\hline 2407 & Computer Engineering & 4005 & Mathematics and Computer Science \\
\hline 2408 & Electrical Engineering & 4006 & Cognitive Science and Biopsychology \\
\hline 2409 & Engineering Mechanics, Physics, \& Science & 5000 & Physical Sciences \\
\hline 2410 & Environmental Engineering & 5001 & Astronomy and Astrophysics \\
\hline 2411 & Geological and Geophysical Engineering & 5002 & Atmospheric Sciences and Meteorology \\
\hline 2412 & Industrial and Manufacturing Engineering & 5003 & Chemistry \\
\hline 2413 & Materials Engineering and Materials Science & 5004 & Geology and Earth Science \\
\hline 2414 & Mechanical Engineering & 5005 & Geosciences \\
\hline 2415 & Metallurgical Engineering & 5006 & Oceanography \\
\hline 2416 & Mining and Mineral Engineering & 5007 & Physics \\
\hline 2417 & Naval Architecture and Marine Engineering & 5008 & Materials Science \\
\hline 2418 & Nuclear Engineering & 5098 & Multi-disciplinary or General Science \\
\hline 2419 & Petroleum Engineering & 5102 & Nuclear, Industrial Radiology, \& Biol. Tech. \\
\hline 2499 & Miscellaneous Engineering & 5901 & Transportation Sciences and Technologies \\
\hline 2500 & Engineering Technologies & 6106 & Health and Medical Preparatory Programs \\
\hline 2501 & Engineering and Industrial Management & 6108 & Pharmacy, Pharmaceutical Sciences, \& Admin. \\
\hline 2502 & Electrical Engineering Technology & 6202 & Actuarial Science \\
\hline 2503 & Industrial Production Technologies & 6212 & Management Information Systems and Statistics \\
\hline
\end{tabular}


Table A2: List of STEM Majors and ACS codes

\begin{tabular}{|c|c|c|c|}
\hline Occ1990 code & Description & Main Definition & Expanded Definition \\
\hline 44 & Aerospace engineer & $\checkmark$ & $\checkmark$ \\
\hline 45 & Metallurgical and materials engineers & $\checkmark$ & $\checkmark$ \\
\hline 47 & Petroleum, mining, and geological engineers & $\checkmark$ & $\checkmark$ \\
\hline 48 & Chemical engineers & $\checkmark$ & $\checkmark$ \\
\hline 53 & Civil engineers & $\checkmark$ & $\checkmark$ \\
\hline 55 & Electrical engineer & $\checkmark$ & $\checkmark$ \\
\hline 56 & Industrial engineers & $\checkmark$ & $\checkmark$ \\
\hline 57 & Mechanical engineers & $\checkmark$ & $\checkmark$ \\
\hline 59 & Not-elsewhere-classified engineers & $\checkmark$ & $\checkmark$ \\
\hline 64 & Computer systems analysts \& computer scientists & $\checkmark$ & $\checkmark$ \\
\hline 66 & Actuaries & $\checkmark$ & $\checkmark$ \\
\hline 67 & Statisticians & $\checkmark$ & $\checkmark$ \\
\hline 68 & Mathematicians and mathematical scientists & $\checkmark$ & $\checkmark$ \\
\hline 69 & Physicists and astronomers & $\checkmark$ & $\checkmark$ \\
\hline 73 & Chemists & $\checkmark$ & $\checkmark$ \\
\hline 74 & Atmospheric and space scientists & $\checkmark$ & $\checkmark$ \\
\hline 75 & Geologists & $\checkmark$ & $\checkmark$ \\
\hline 76 & Physical scientists, n.e.c. & $\checkmark$ & $\checkmark$ \\
\hline 77 & Agricultural and food scientists & $\checkmark$ & $\checkmark$ \\
\hline 78 & Biological scientists & $\checkmark$ & $\checkmark$ \\
\hline 79 & Foresters and conservation scientists & $\checkmark$ & $\checkmark$ \\
\hline 83 & Medical scientists & $\checkmark$ & $\checkmark$ \\
\hline 229 & Computer software developers & $\checkmark$ & $\checkmark$ \\
\hline 84 & Physicians & & $\checkmark$ \\
\hline 85 & Dentists & & $\checkmark$ \\
\hline 86 & Veterinarians & & $\checkmark$ \\
\hline 87 & Optometrists & & $\checkmark$ \\
\hline 88 & Podiatrists & & $\checkmark$ \\
\hline 89 & Other health and therapy diagnosing occupations & & $\checkmark$ \\
\hline 96 & Pharmacists & & $\checkmark$ \\
\hline 113 & Earth, environmental, and marine science instructors & & $\checkmark$ \\
\hline 114 & Biological science instructors & & $\checkmark$ \\
\hline 115 & Chemistry instructors & & $\checkmark$ \\
\hline 116 & Physics instructors & & $\checkmark$ \\
\hline 127 & Engineering instructors & & $\checkmark$ \\
\hline 128 & Math instructors & & $\checkmark$ \\
\hline
\end{tabular}

